\title{
C. 2
}

PREPARATION OF RESIDUAL GRAVITY MAPS FOR THE SOUTHERN CASCADE MOUNTAINS, WASHINGTON USING FOURIER ANALYSIS

By

Debra McLean Dishberger

April 1983

Work Performed Under Contract No. AC07-79ET27014

Washington Department of Natural Resources

Olympia, Washington

Technical Information Center

Office of Scientific and Technical Information

United States Department of Energy 


\section{DISCLAIMER}

This report was prepared as an account of work sponsored by an agency of the United States Government. Neither the United States Government nor any agency Thereof, nor any of their employees, makes any warranty, express or implied, or assumes any legal liability or responsibility for the accuracy, completeness, or usefulness of any information, apparatus, product, or process disclosed, or represents that its use would not infringe privately owned rights. Reference herein to any specific commercial product, process, or service by trade name, trademark, manufacturer, or otherwise does not necessarily constitute or imply its endorsement, recommendation, or favoring by the United States Government or any agency thereof. The views and opinions of authors expressed herein do not necessarily state or reflect those of the United States Government or any agency thereof. 


\section{DISCLAIMER}

Portions of this document may be illegible in electronic image products. Images are produced from the best available original document. 


\title{
DISCLAIMER
}

\begin{abstract}
This report was prepared as an account of work sponsored by an agency of the United States Government. Neither the United States Government nor any agency thereof, nor any of their employees, makes any warranty, express or implied, or assumes any legal liability or responsibility for the accuracy, completeness, or usefulness of any information, apparatus, product, or process disclosed, or represents that its use would not infringe privately owned rights. Reference herein to any specific commercial product, process, or service by trade name, trademark, manufacturer, or otherwise does not necessarily constitute or imply its endorsement, recommendation, or favoring by the United States Government or any agency thereof. The views and opinions of authors expressed herein do not necessarily state or reflect those of the United States Government or any agency thereof.
\end{abstract}

This report has been reproduced directly from the best available copy.

Available from the National Technical Information Service, U. S. Department of Commerce, Springfield, Virginia 22161.

Price: Printed Copy A03

Microfiche A01

Codes are used for pricing all publications. The code is determined by the number of pages in the publication. Information pertaining to the pricing codes can be found in the current issues of the following publications, which are generally available in most libraries: Energy Research Abstracts (ERA); Government Reports Announcements and Index (GRA and I); Scientific and Technical Abstract Reports (STAR); and publication NTIS-PR-360 available from NTIS at the above address. 
STATE OF WASHINGTON DEPARTMENT OF NATURAL RESOURCES

BRIAN J. BOYLE, Conmissioner of Publ ic Lands JAMES A. STEARNS, Department Supervisor

DIVISION OF GEOLOGY AND EARTH RESOURCES

Raymond Lasmanis, State Geologist

PREPARATION OF RESIDUAL GRAVITY MAPS FOR THE

SOUTHERN CASCADE MOUNTAINS, WASHINGTON USING FOURIER ANALYSIS

April 1983

by

Debra McLean Dishberger

Washington Department of Natural Resources

Division of Geology and Earth Resources

07ympia, WA 98504

Open-File Report 83-4 
CONTENTS

\section{Page}

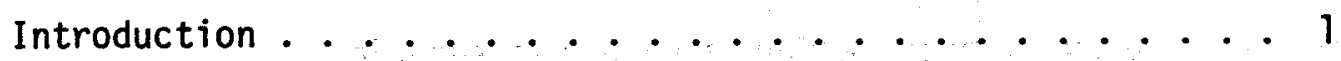

Residual separation method ............. 1

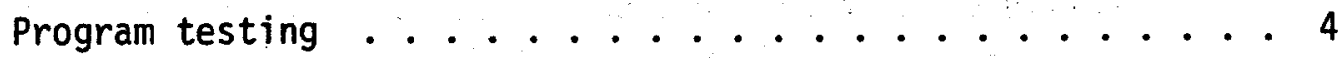

Cutoff wavelength selection .......... 8

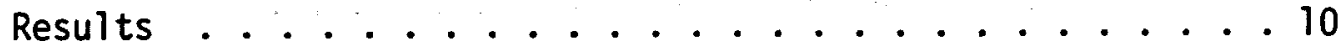

References cited ................. 11

Appendix A - FORTRAN Program RESIDUAL .......... A-1

Appendix B - FORTRAN Program SPECTRA ............ B-1 


\section{ILLUSTRATIONS}

Page

Figure 1. Gravity profile for two spheres superimposed upon a planar field............ 5

2. Profile of test case regional field . . . . . . 6

3. Profile of test case residual field . . . . . . . 7

4. Idealized power spectrum plot ........... 9

5. Power spectrum of gravity data from the Southern Cascade Mountains, Washington . . . . . 11

Plate 1. Residual gravity map of the Southern Cascade Mountains, Washington - 85 kilometer cutoff wavelength ............. Back Pocket

2. Residual gravity map_of the Southern

Cascade Mountains, Wastington - 40 kilometer cutoff wavelength ........... Back Pocket

3. Residual gravity map of the Southern

Cascade Mountains, Washington - 20 kilometer cutoff wavelength . . . . . . . . . Back Pocket 


\section{INTRODUCTION}

This report represents a continuation of gravity work in the Cascade Mountains of Washington supported by the Division of Geology and Earth Resources since 1974. The purpose of this research has been collection of baseline gravity data for use in geothermal resource evaluation. Results of the Division's gravity studies to date are given in Danes and Phillips (1983a, 1983b).

One of the problems encountered when analyzing gravity data is distinguishing between those parts of the data that represent geologic structures of interest, and those that do not. In many cases, the features of interest are relatively small, near-surface features, such as those sought in mineral, petroleum, or geothermal exploration. Gravity anomalies caused by such structures may be distorted or masked by anomalies caused by larger, deeper geologic structures. Gravity anomalies caused by relatively shallow, small geologic structures are termed residual anomalies. Those due to broad, deep-seated features can be described as regional anomalies.

The purpose of this report is to describe a fourier analysis method for separating residual and regional gravity anomalies from a complete Bouguer gravity anomaly field. The technique has been applied to gravity data from the Southern Cascade Mountains, Washington. Residual gravity anomaly maps at a scale of $1: 250,000$ are presented for various regional wavelength filters, and a power spectrum of the frequency components in the South Cascade gravity data is displayed. No attempt is made to interpret the results of this study in terms of geologic structures.

\section{RESIDUAL SEPARATION METHOD}

The method used here to separate regional and residual anomalies is based on the assumption that regional anomalies are distinctly larger 
than residual anomalies. This implies that the spatial wavelengths of anomalies caused by regional features are longer than the wavelengths of anomalies die to local structures. It also must be assumed that the two do not overlap appreciably. If these assumptions are true, regional-residual separations can be made by filtering out wavelengths of the gravity field that represent undesired information. This filtering process is carried out with Fourier analysis.

Detailed discussions of Fourier analysis and regional-residual separation of gravity fields are given in Clemont (1972), Cordell and Grauch (1982), and Gupta and Ramani (1980). Briefly, Fourier analysis is based on the fact that a periodic function can be expressed as the sum of a series of sine and cosine waves of various frequencies. Each sine and cosine wave making up a part of the sum is called a frequency component. By using a procedure known as the Fourier transform, the magnitude of the frequency components for a given function can be determined. Since frequency is the reciprocal of wavelength, each frequency component represents a particular spatial wavelength present in the data. Thus, removal of a group of wavelengths form a data set can be accomplished by setting the corresponding frequency components to zero.

A FORTRAN computer program, RESIDUAL, was developed to perform the desired wavelength filtering. Source code and documentation for RESIDUAL are presented in Appendix A. Much of the source code for the computer program is after Pitts (1979). The routine to perform the Fourier transfrom is from IBM (1966).

The program RESIDUAL is designed to run on an IBM 3033 with a FORTRAN G compiler. Users familiar with FORTRAN should have little trouble using the program with other computer systems that support FORTRAN.

Program RESIDUAL takes a digitized grid of gravity data and filters 
out anomalies with dimensions greater than the specified size. The digitized data is read into the computer along with the cutoff wavelength. Before the Fourier transform is performed, several steps are taken to minimize distortions of the data caused by the transform process. Most distortions are caused by abrupt changes in data values, either in the function's spatial or frequency representations.

The first step in reducing distortion is removal of a first. order trend from the data. This is done to el iminate power in the zero frequency component of the frequency spectrum. Otherwise, this component will be much greater than the other components, which could lead to inaccuracies in the inverse transform process. The first order trend is restored to the data matrix following the inverse transform process.

To prevent unexpected results due to the abrupt termination of data at the edge of the matrix, the data is extended on all sides of the map area and values tapered smoothly to zero. At this point, the Fourier transform is performed. The spatial function described by the input matrix is converted into a frequency representation. The filtering process is carried out by setting to zero those frequency components representing spatial wavelengths shorter than the specified cutoff wavelength. The frequency function thus obtained is the regional gravity field.

An inverse fourier transform is next performed to obtain a spatial representation of the regional field. The regional field is extracted from the center of the extended matrix and the first order trend removed earlier is restored. The residual field is then computed by subtracting the regional field from the input data. Program output consists of the residual and regional data matrices. Rows and columns of each matrix are labeled with latitude and longitude values or any other convenient coor- 
dinate system. The program utility could be greatly enhanced by adding a plotter routine for automated posting and contouring of the data.

\section{PROGRAM TESTING}

In order to be confident that the program actually separates the various components of a gravity field as intended, a simple test case was developed. This test case consisted of a theoretical gravity anomaly caused by two spheres of varying density. The larger sphere was twice as large as the smaller sphere and was buried three times as deeply. Gravity effects from the spheres were superimposed on a planar regional gravity field. A profile across the total gravity field is shown in Figure 1.

The task of the computer program was defined to be separation of gravity effects due to the smaller sphere from the remainder of the theoretical field. Figure.2 shows a profile of the regional field produced by the program RESIDUAL. Figure 3 is a profile of the residual gravity anomaly calculated by the program. These results indicate that a good separation of anomalies was achieved by the program.

Further testing of the program revealed that some distortion of the data was occurring despite trend removal and elimination of edge effects. The distortion is visible in contoured maps of regional fields as "ripples" symmetric about the map area, i.e. ripples tended to be present along lines dividing the map area into quarters and eighths. The amplitude of the distortion did not exceed several mgals. While the cause of the distortion is not fully understood, a simple solution was devised. Following production of the regional field, the data matrix is handsmoothed by contouring. Data values corresponding to the distorted areas are removed and replaced with values that permit smooth contouring. Because regional maps have simple geometries, contouring is rapid and 


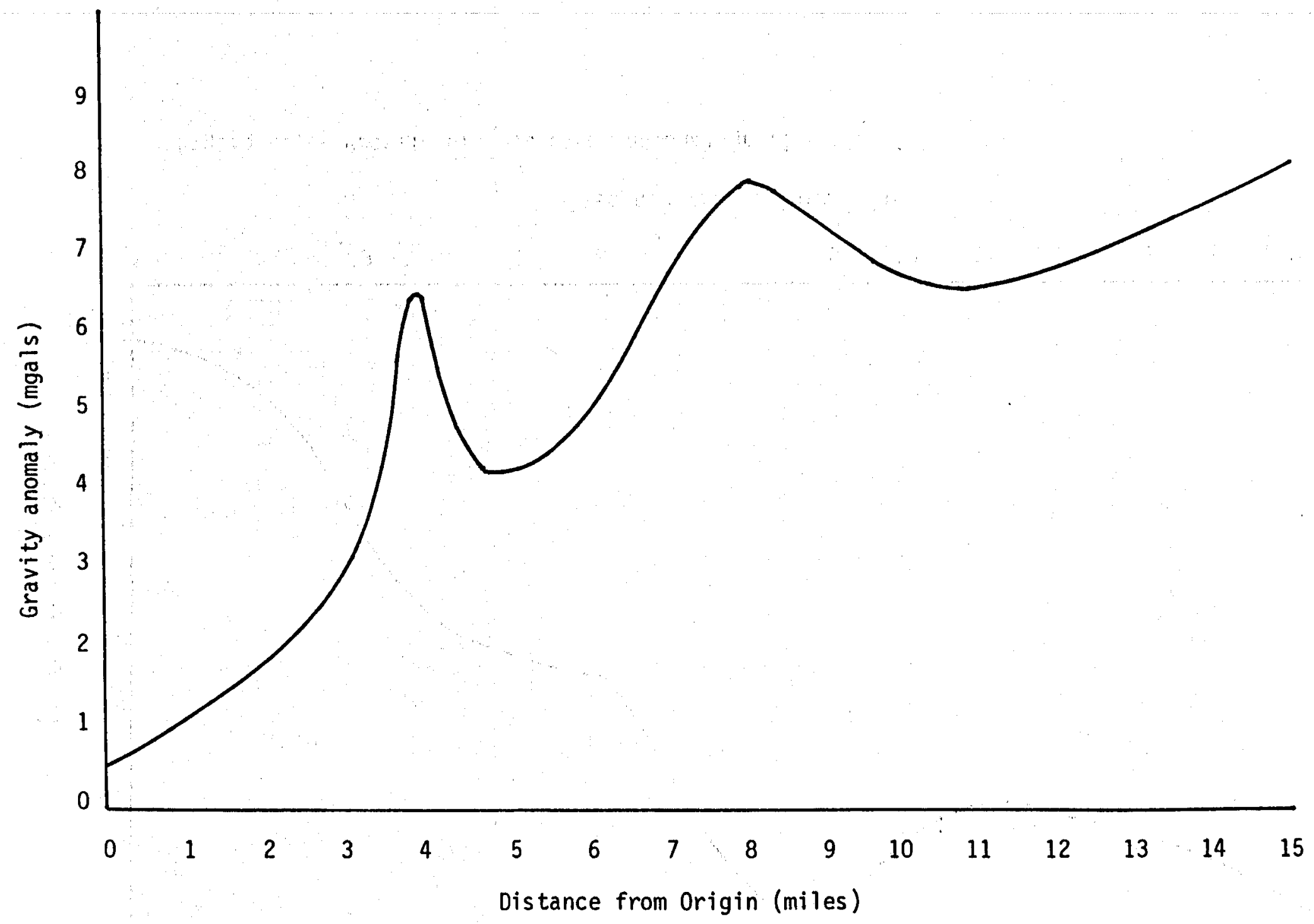

Figure 1. - Gravity profile for two spheres superimposed upon a planar field. 


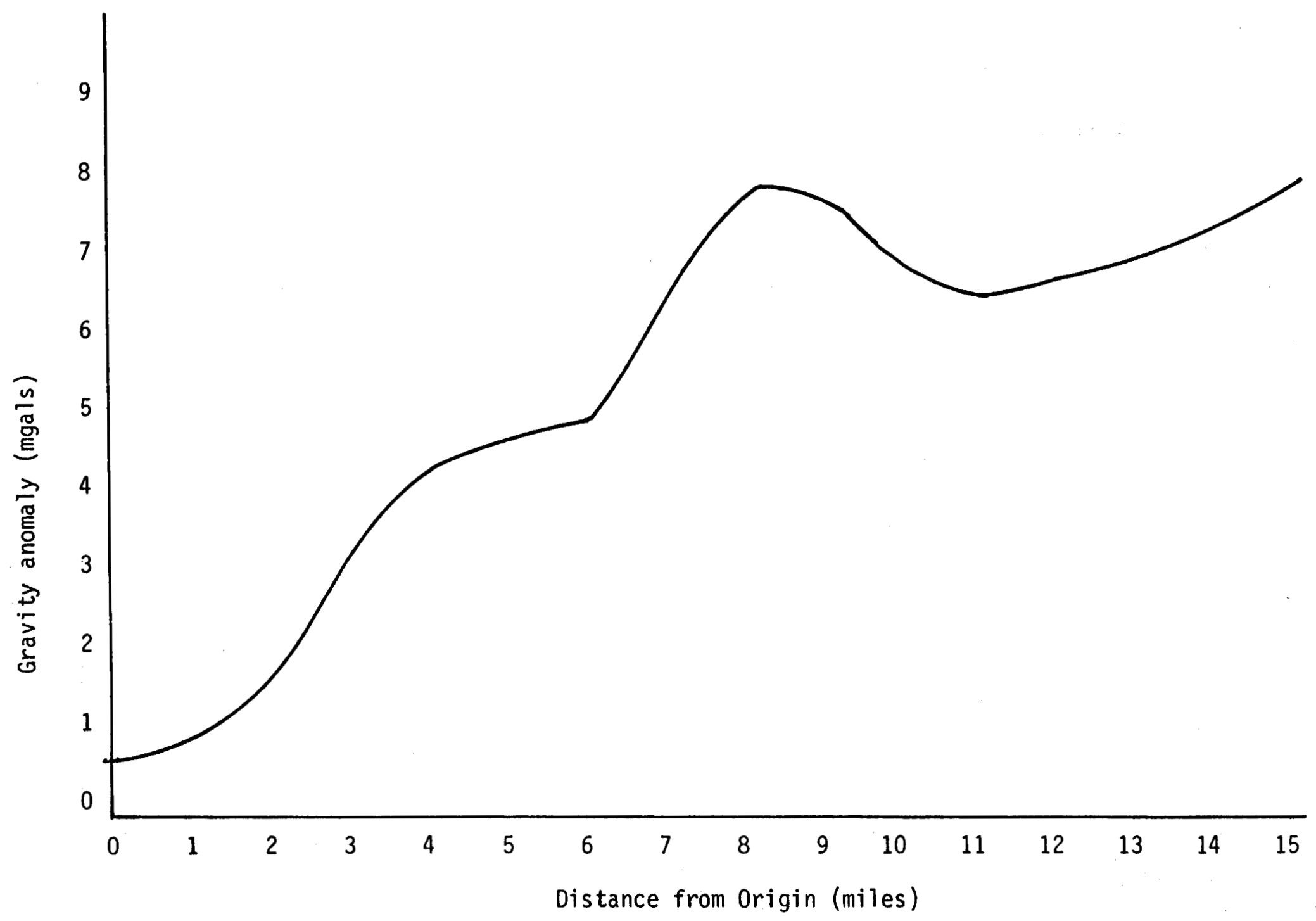

Figure 2. - Profile of test case regional gravity field. 


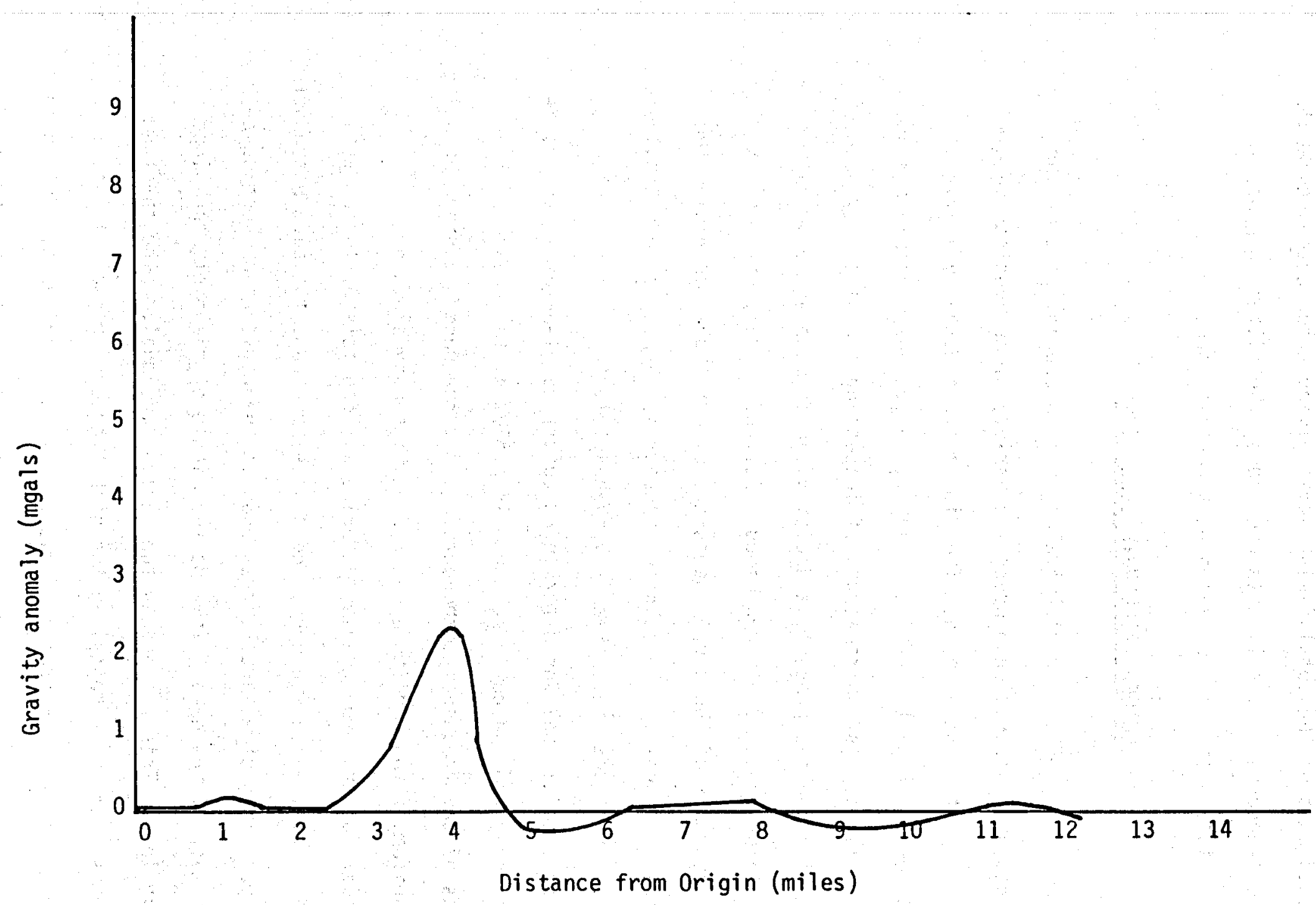

Figure 3. - Profile of test case residual field. 
unambiguous. The corrected portion of the data is then subtracted from the affected part of the total field matrix giving a corrected residual. This process ensures that artifacts created by the filtering process will not be interpreted as anomalies on a residual map.

\section{CUTOFF WAVELENGTH SELECTION}

The selection of the cutoff wavelength is a crucial part of the residual-regional separation process. A variety of methods can be used to select the cutoff wavelength. The simplest conceptually is visual inspection of the data to be used as input. A contoured complete Bouguer gravity map is the most suitable way of inspecting the data. By observing the sizes of anomalies present, a decision can be made as to which features should be enhanced or suppressed. Desired anomaly size is, of course, a function of the user's needs and expectations concerning the shape, size, and density of geologic structures. Hence, a good knowledge of the geology of the study area is very helpful.

Another useful tool for determining cutoff wavelengths is an amplitude power spectrum. A power spectrum is a plot of the square of the amplitudes of the frequency components against frequency. Using the natural logarithm of the amplitude squared permits easy plotting.

A power spectrum for gravity data ideally consists of three parts (Figure 4). At the low frequency end of the spectrum, the plot has a very steep siope. This steep area corresponds to the regional or long wavelength portion of the data. Towards the middle of the plot, the slope is notably less. This represents the residual "signal." The spectrum plot becomes nearly horizontal in the high frequency range. The flat area is often taken to represent "noise" present in the data. The noise may correspond to errors in digitizing and gravity field measurement, or simply very small wavelength anomalies. 


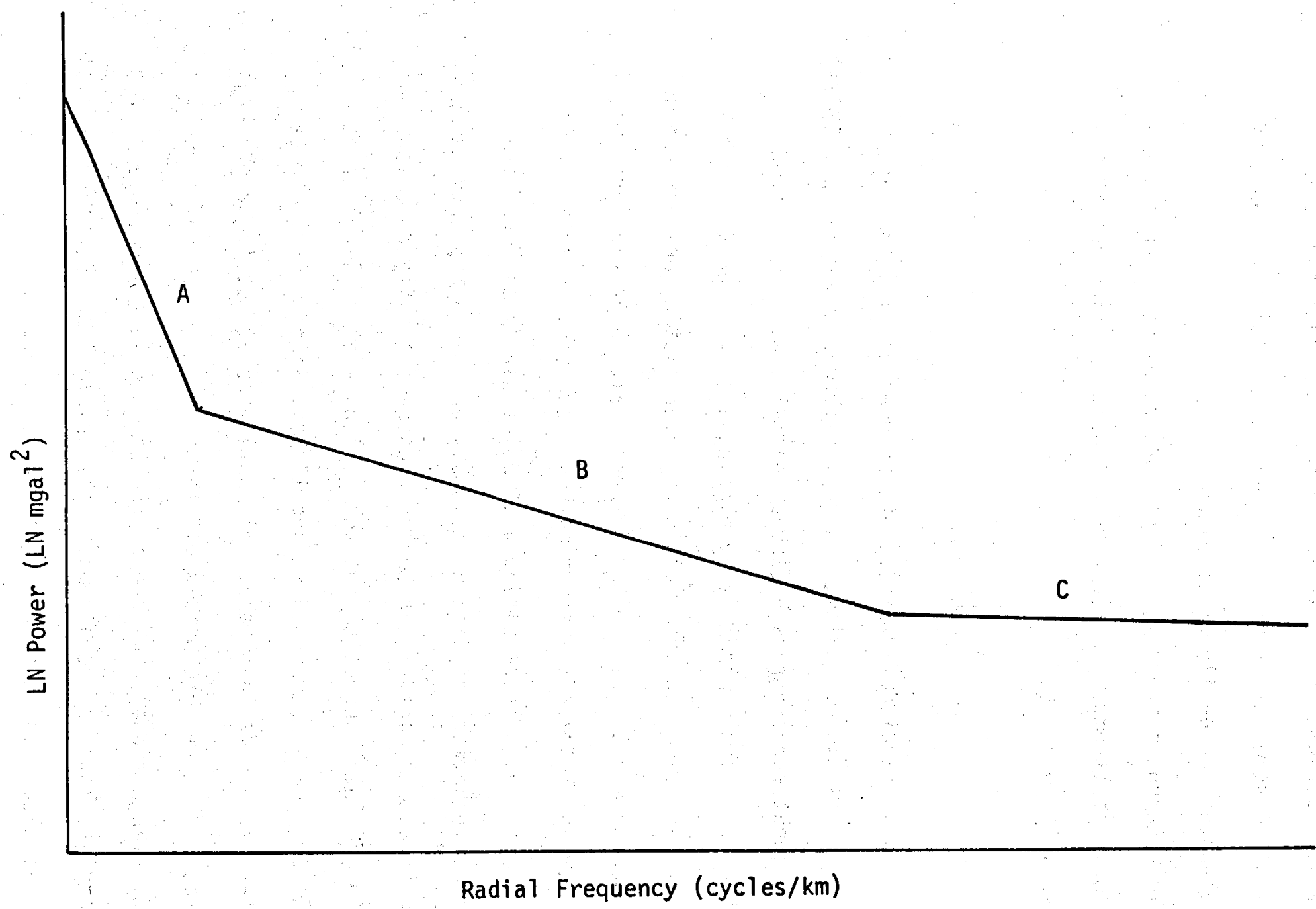

Figure 4. - Idealized power spectrum plot. A marks the position of the regional portion of the plot; $B$, the residual; and C, "noise". 
Choice of a cutoff wavelength is made by identifying the graph's inflection point from the steep, regional slope to an intermediate, residual value. Because the power spectrum is a smooth curve, this decision is often somewhat arbitrary. However, a suitable range of cutoff wavelengths can easily be obtained.

A FORTRAN computer program, SPECTRA, was developed to calculate amplitude power spectrums. Source code and documentation for SPECTRA are provided in Appendix $B$.

\section{RESULTS}

Gravity data contained in a complete Bouguer gravity anomaly map of the Southern Cascade Mountains, Washington (Danes and Phillips, 1983a) were used as input for programs RESIDUAL and SPECTRA. A digitized representation of the map was made by placing a $64 \times 64$ grid over the map and assigning values to grid points by interpolating between contour lines. Values were estimated to the nearest mgal. A $64 \times 64$ grid was chosen because the Fourier transform method used requires data matrices to be a power of two. The resulting 4096-point matrix also represents a good compromise between digitizing accuracy and rapid map production.

A power spectrum plot of the Southern Cascade gravity data is shown in Figure 5. The plot suggests that the regional-residual cutoff wavelength falls somewhere between $90 \mathrm{~km}$ and $15 \mathrm{~km}$. Since a unique wavelength filter was not defined, three residual maps of cutoff wavelengths $20 \mathrm{~km}, 40 \mathrm{~km}$, and $85 \mathrm{~km}$ were produced. These maps are presented in Plates 1,2 , and 3 . The residual maps are at the same scale $(1: 250,000)$ as the original complete Bouguer anomaly map. The original map contour interval of $5 \mathrm{mgals}$ was also used in preparing the residual maps. 


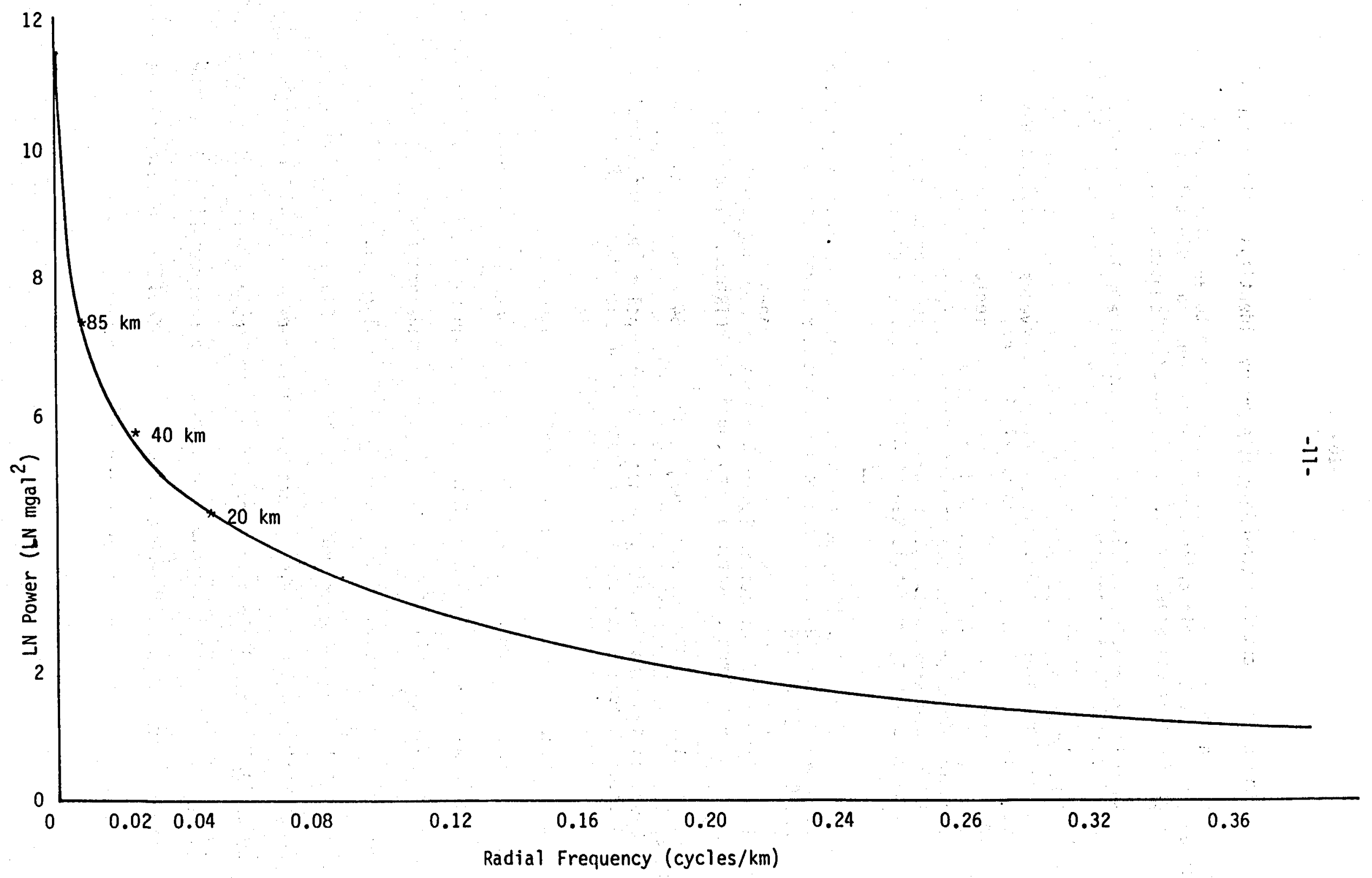

Figure 5. - Power spectrum of gravity data from the Southern Cascade Mountains, Washington. Position of $85 \mathrm{~km}$, $40 \mathrm{~km}$, and $20 \mathrm{~km}$ cutoff wavelengths are indicated. 


\section{REFERENCES CITED}

Clement, W.G., 1973, Basic principles of two-dimensional digital filtering: Geophysical Prospecting, v. 21, p. 125-145.

Cordell, Lindrith; Grauch, V.J.S., 1982, Reconciliation of the discrete and integral Fourier transforms: Geophysics, v. 47, no. 2, p. 237-243.

Danes, Z.F.; Phillips, W.M., 1983a, Complete Bouguer gravity anomaly map, Cascade Mountains, Washington: Washington Division of Geology and Earth Resources Geophysical Map GM-27, 2 sheets.

Danes, Z.F.; Phillips, W.M. 1983b, Principal facts and a discussion of terrain corrections for the complete Bouguer gravity anomaly map, Cascade Mountains, Washington: Washington Division of Geology and Earth Resources, Open-file Report 83-1, 15 p., 145 gravity data sheets.

Gupta, V.K.; Ramani, N., 1980, Some aspects of regional-residual separation of gravity anomalies in a Precambrian terrian: Geophysics, v. 45, no. 9 , p. $1412-1426$.

IBM, 1966, System/360 Scientific Subroutine Package (360 A-CM-03X) Programmer's Manual: International Business Machines, White Plains, New York. $454 \mathrm{p}$.

Pitts, G.S., 1979, Interpretation of gravity measurements made in the Cascade Mountains and adjoining Basin and Range Province in Central Oregon: Oregon State University Master of Science thesis, $186 \mathrm{p}$. 
A- $i$

Appendix A

FORTRAN Program RESIDUAL 
**** TSO FOREGROUND HARDCOPY ****

DSHAME $=$ WPGG490. RESIDUAL. PRG

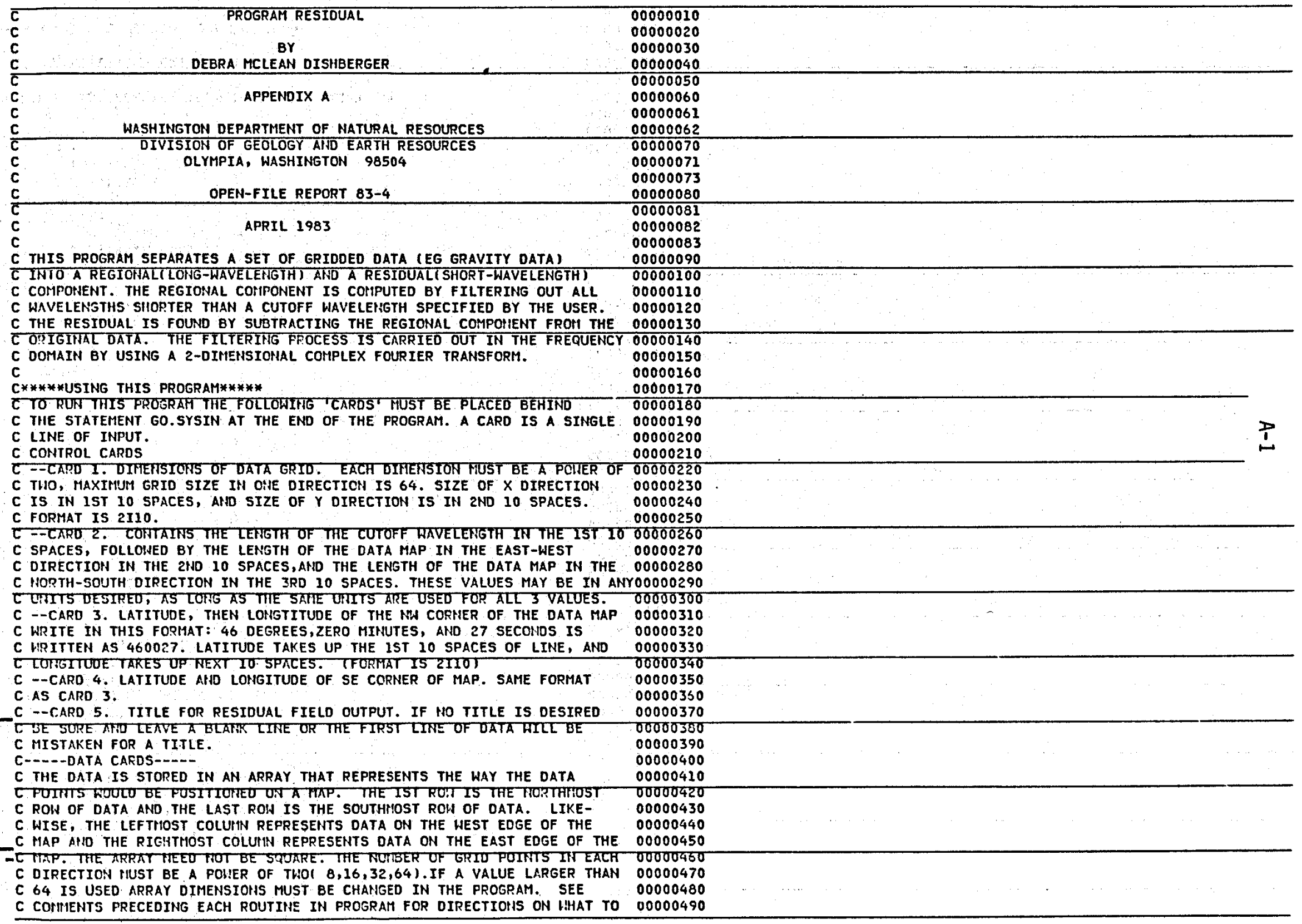


C CHARGE AND HOW TO CHANGE IT. THE DATA ARRAY IS READ IN STRIPS OF 8

C COLUIIIS AT A TIME. EACH DATA CARD HOLDS 8 VALUES IN A 8F7.0 FORMAT

C FOR EXAMPLE, IF THERE 32 ROWS OF DATA AND 64 COLUHNS OF DATA, THE

C $15 T 32$ CARDS HOLD VALUES FOR COLUMNS 1-8, THE 2ND 32 COLUMNS HOLD

C VALUES FOR COLUMNS 9-16, AND SO ON. IN THIS CASE, THERE HOULD BE

C 8 SUCH SETS OF 32 CARDS.

DIMENSION SMLARY $(64,64), \operatorname{BGARY}(2,128,120)$, TREND (3), MHARM( 3$)$

DIFEIISIOH SIGII 4096$),$ INV(4096), TOTFLD $(64,64)$, RESTRN( 3$)$

INTEGER GRIDX, GRIDY,TITLE (20), RECNVR

COMMON/DATAL/SMLARY/DATA2/BGARY/DATA3/SIGN, INV

GRIDX,GRIDY

LARGEX $=2 *$ GRIDX

LARGEY $=2$ * GRIDY

READ $(5,5)$ CUTOFF, XSIZE, YSIZE

5 FORIAT (3F10.2)

READ $(5,10)$ LATNW, LOHGHW

READ $(5,10)$ LATSE, LONGSE

10 FORHAT (2I1O)

READ $(5,20)$ TITLE

20 FOPMAT(20A4)

DO $50 \mathrm{I}=1$, GRIDX, 8

DO $40 \mathrm{~J}=1$, GRIDY

$L=I+7$

$\operatorname{READ}(5,55)(\operatorname{SMLARY}(J, K), K=I, L)$

40 CONTIRIUE

50 CONTINUE

55 FORारTा8F.0T

C SAVE ORIGINAL DATA

DO $70 I=1$, GRIDX

$0060 \mathrm{~J}=1$, ERIOY

$\operatorname{TOTFLD}(I, J)=\operatorname{SMLARY}(I, J)$

60 CONTINUE

70 Contrinue

C COMPUTE DECIMAL EQUIVLANTS OF LATITUDE AND LONGITUDE

DLATHW = COINER (LATNW)

DLFIGIN = CONVER ( LONIGHN)

DLATSE = CONVER(LATSE

DLNGSE = CONVER (LONGSE)

c

C INITIALIZE BGARY

DO 200 I=IILARGEX

DO $100 \cdot \mathrm{J}=1$, LARGEY

BGARY $(2, I, J)=0.0$

-100 CONTIIUE

200 CONIITUE

c COMPUTE FAST FOURIER TRANSFORM OF GRIDDED DATA

CALL FFTSETITRETO,GRIUX,GRIOI

C set the parameters needed to enter harm

IOPT $=1$

EC TIIU TIIE LOS BASE 2 OF GRIOX ATSO GRID

DO $385 I=1,10$

$M=2 * * I$

IF ( M.EQ.LARGEX) MHARM(1) = I
00000540

00000550

00000560

00000570

00000580

00000590

00000600

00000610

00000620

00000630

00000640

00000650

00000660

00000670

00000680

00000690

00000700

00000710

00000720

00000730

00000740

00000750

00000760

00000770

00000780

00000790

00000800

00000810

00000820

00000830

00000840

00000850

00000860

00000870

00000880

00000890

$00000 \% 00$

00000910

00000920

00000930

00000940

00000950

00000960

00000970

00000980

00000990

00001000

00001010

00001020

00001030

00001040

00001050

00001060

00001070

00001080 
HARH IS THE ROUTINE THAT ACTUALLY CALCULATES THE FOURIER TRANSFORMO0001140

CALL HAPMLMHAPM, IOPT, IFGOOF I

C CALL FILTERTLAREEX, LARGEY, MHARM, CUTOFF, XSIZE, YSIZE) $\quad 00001170$

c $\quad 00001190$

$\begin{array}{ll}\text { CALL STRIPIGRIDX,GRIDY } & 00001200\end{array}$

c $\quad 00001210$

0001220
0

C WRITE 16,400 ( 00001230

$\begin{array}{lr}\text { C WRITE }(6,400) & 00001240 \\ \text { C400 FORTATIIHI, INPUT DATA I } & 00001250\end{array}$

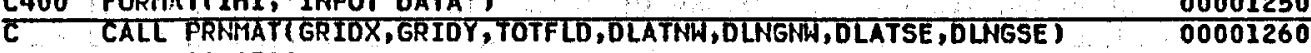
00001270

450 FORMAT(1H1,'REGIONAL FIELD') 00001280

CALL FRMMAT( GRIOX, GRIOY, SMLARY, DLATHM,DLNGM, DLATSE, DLNGSE) $\quad 00001290$

C COMPUTE RESIDUAL--RESIDUAL = TOTAL FIELD-REGIONAL FIELD $\quad 0000130$

C CONYERTS IT BACK INTO DEGREES, MITUTES, AND SECOTIDS. FOR EXAMPLE, 00003680

C 45.5083 DEGREES BECOMES $453030 \quad 00001690$ 
C SET DIHENSIOHS OF MAT TO GRIDX, GRIOY

00001830 THIS ROUTINE PRINTS OUT A MATRIX.

00001840

PARAMETERS ARE: NX, THE $X \quad 00001650$

C DIPIENSION: NY, THE Y DIMENSION; AND MAT, WHICH SPECIFIES THE 00001860

$\begin{array}{ll}C & 00001870\end{array}$

$\begin{array}{lll}\text { c } & \text { SET INCREMENTS FOR PRINTING LATITUDE AND LONGITUDE } & 00001880 \\ \text { C } & 00001890\end{array}$

C SET INCREMENTS FOR PRINTING LATITUDE ANO LONGITUDE

LATINC = (OLNGHW - DLNGSEI/FLOAT(NX)

00001910

DO $100 K=1, N Y, 8$

$L=K+7$

C. PRINT LONGITUDE HEADINGS

DO $20 I=1,8$

$J=K+I-I$

LOHG (I) = RECNVR (DLNGNW-FLOAT ( J-1)*LNGINC)

00001920

00001930

00001950

00001960

00001970

20 CONIINUE

WRITE $(6,110)($ LOHG $(I), I=1,8$

Do $50 \mathrm{I}=\mathrm{I}$, NX

LAT = RECNVRI DLATHW - (LATINC*FLOAT(I-1))

WRITE(b,I5O) LAT, (FATTI,J),J $=K, L)$

50 Colit IHUE

CONTINUE

RETURN

IIO FORFATTIHO, 7X,8F7.I

150 FORMAT (1HO, I10, BF 7.1)

END

00001980

00001990

00002000
00002010

00002020

00002030

00002040

00002050

00002060

00002070

00002080

00002090

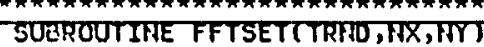

00002110

THIS SUEROUTINE PREPARES THE DATA FOR THE FOURIER TRANSFORM PROCESS O0002120

C PARAHETERS ARE TRND, A 3-ELEMENT VECTOR THAT HOLDS A DESCRIPTION OF 00002130

C. A PREWHITENING COEFFICIENT. NX ARD NY ARE THE $X$ AND $Y$ DIMENSIONS OF 00002150

C THE DATA GRIO. ACTIONS PERFORHED BY FFTSET: $\quad 00002160$

C 1). FINDS A BEST FITTIHG 1ST ORDER TREHD SURFACE THROUGH THE DATA O0002170

C AIIO RETIOVES II. THIS RETIOVES POIER FRON THE DC COTPOHENT OF THE 00002100

FREQUENCY SPECTRUM. THE TRENO IS ADDED BACK TO THE REGIONAL DATA 00002190

C AFTER THE FILTER PROCESS.

C 2). TAPERS THE DATA. THE FOURIER TRAHSFORM WILL MORE ACCURATLY 00002210

$C$ REFRESENT THE UATA IF THAT DATA DOES WOT 'DROP OFF' AT THE

C EDGE OF THE GRID. THE GRID IS EXTENDED BY TAPERING THE VALUES 00002230

C AT THE EDGE OF THE GRID TO ZERO USING A COSINE SQUARED WEIGHTING 00002240

C FURICTION. A PAD OF ZEROS IS PLACED AROUND THIS ENTIRE MATRIX TO

C C CRETIE ATTHA GRTD

GRID IS CALLED TAPER.

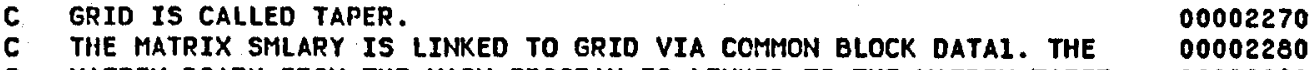

00002250

00002250

MATRIX BGARY FROM THE MAIN PROGRAM IS LIIKED TO THE MATRIX TAPER 00002290


SET THE DIMENSIONS OF GRD TO BE GRIDX, GRIDY

SET THE DIMENSIOHS OF TAPER TO BE 2,2*GRIDX,2*GRIOY 00002360

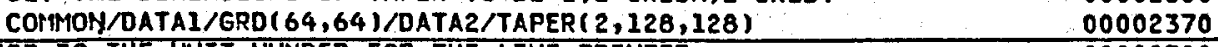

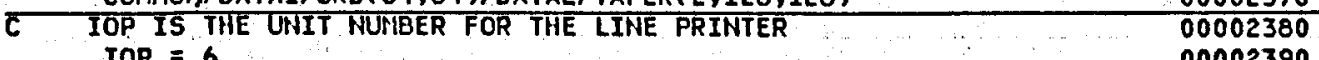

$\begin{array}{ll}\text { IOP }=6 & 00002390\end{array}$

00002400

NY2 $=2 *$ NY $\quad 00002410$

NXB4 $=N X / 4 \quad 00002420$

$\begin{array}{rr}\text { NYB4 }=\text { NY/4 } & 00002430\end{array}$

NXB2 $=$ NX/2, $\quad 00002440$

$\begin{array}{lr}\text { NYB2 }=\text { NY/2 } & 00002450^{\circ}\end{array}$

00002460

00002470

NY32 = J*NYB2 $\quad 00002480$

$\begin{array}{ll}\text { NXML }=N X-1 & 00002490 \\ \text { NYMI }=N Y-1 & 00002500\end{array}$

$\begin{array}{ll}\text { NYMI }=\text { NY } & 00002500 \\ P I=3.141592653 & 00002510\end{array}$

$\begin{array}{ll}\text { PIXB4 }=\text { PI/NXB4 } & 00002520\end{array}$

PIYB4 = PI/MYB4 $\quad 00002530$

C

CALL FTREND(TRND, NX,IYY) $\quad 00002550$

\begin{tabular}{ll}
$C$ & 00002560 \\
\hline &
\end{tabular}

$\begin{array}{ll}\text { C SET TAPERING PARAMETERS } & 00002570\end{array}$

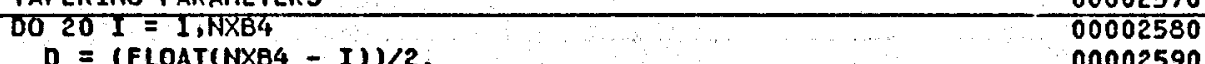

$D=($ FLOAT $(N X B 4-I)) / 2 . \quad 00002590$

WTX(I) $=(1-\cos ($ PIXB4*D)**2) $\quad 00002600$

20 COHTIHUE

00002600

DO $30 I=1$, WYBS 00002620

$\begin{array}{ll}0=\text { (FLOATINYB4 - I)I/2. } & 00002620 \\ 00002630\end{array}$

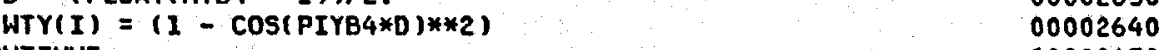

$\begin{array}{lr}30 \text { CONTINUE } & 00002650\end{array}$

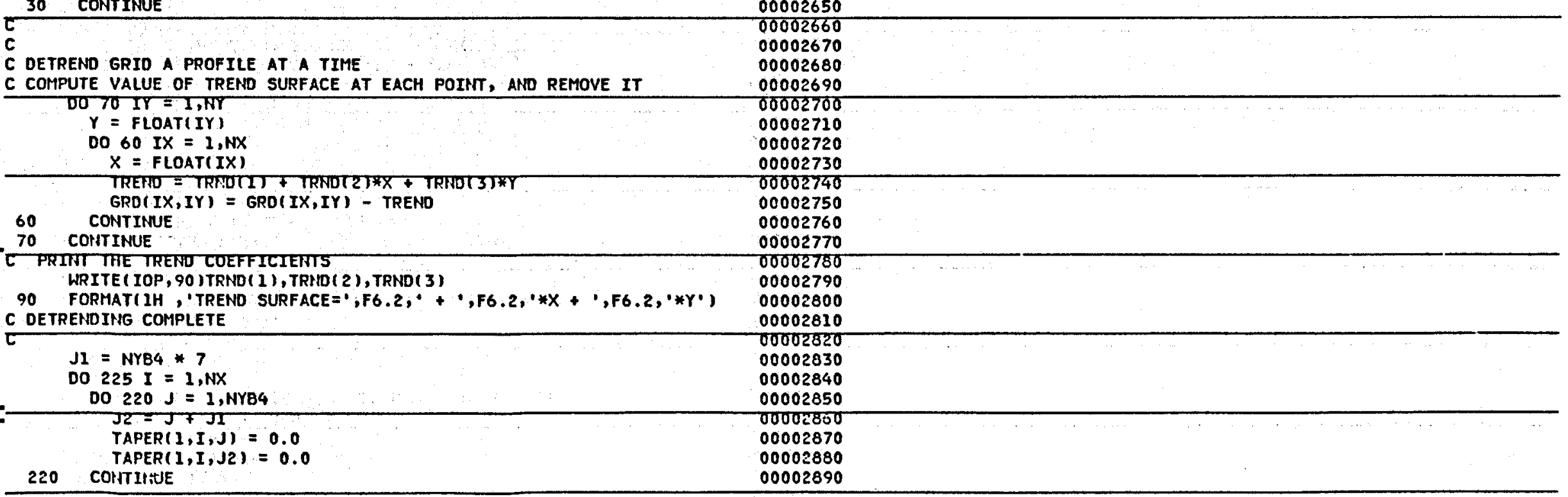


c

C place matrix gro in the center of the matrix taper

00002970

DO 270 IYl $=1$, NY

IYS $=$ IYI $\bullet$ NYB2

00002990

00003000

DO 240 IXI = I,NX

00003010

IX2 $=I \times 1+$ NXB2

TAPER( $1, I \times 2, I Y 2)=$ GRD(IXI,IYI)

00003020

00003030

00003040

CONTIINUE

C TAPER EACH PROFILE

00003040

c

DO $250 I=1, N \times B 4$

00003070

00003080

$I P=(N X B 2+I)-I$

$J P=(3 * N \times B 2)+1$

$\begin{array}{ll}\text { IP }=(N X B 2+I)-I & 00003100 \\ \text { JP }=(3 * N X B 2)+I & 00003110 \\ \text { TAPER }(1, I P, I Y 2)=\text { GRD }(1, I Y 1) * N T X(I) & 00003120\end{array}$

00003090

$\begin{array}{ll}00003120 & 0003130\end{array}$

$$
250 \text { COINTINUE }
$$

270 CONTINUE

00003130

00003150

00003160

TAPER PROFILES IN THE Y DIRECTION

DO $300 I=1, N X$

DO $280 \mathrm{~J}=1$, NYB

$t_{t}=33-J$

$K=96+J$

280 CONTINUE

RETU?T
END

c

00003230

00003240

00003250

00003270

00003270

00003280

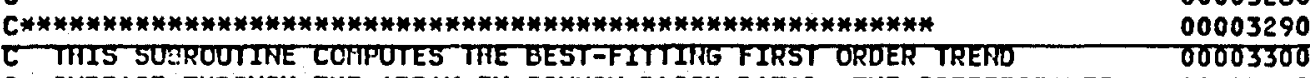

C SURFACE THROUGY THE ARRAY IN COMMON BLOCK DATAI. THE COEFFICIENTS 00003310

C THAT DESCRIBE THE TREND SURFACE ARE IN THE MATRIX COEF NY AHD NY 00003320

C ARE THE DIHENSIONS OF THE ARRAY IN DATAI. AKID SHOULD BE SET TO 0003320

$C$ ARE THE DIFENSIONS OF THE ARRAY IN DATAI, ANIO SHOULD BE SET TO
$C$ THE VALUES OF GRIOX ANO GRIOY.

C THE VALUES OF GRIUX AIND GRIOT.

\begin{tabular}{|c|c|c|}
\hline C & $\begin{array}{l}\text { SUBROUTINE FTREND(COEF,NX,NY) } \\
\text { COMMON/DATAI/GRID }(64,64)\end{array}$ & $\begin{array}{l}00003350 \\
00003360 \\
00003370\end{array}$ \\
\hline C SET & $\begin{array}{l}\text { DIMETSTON COEFTJ,ST3,3T,GT3 } \\
\text { DETREND PARAMETERS } \\
\text { DO } 10 \mathrm{I}=1,3\end{array}$ & $\begin{array}{l}00003380 \\
00003390 \\
00003400 \\
00003410\end{array}$ \\
\hline$\cdots$ & $\begin{array}{l}\operatorname{COEF}(I)=0.0 \\
\operatorname{DO} 9 \mathrm{~J}=1,3 \\
s(J, I)=0.0\end{array}$ & $\begin{array}{l}00003420 \\
00003430 \\
00003440 \\
00003450\end{array}$ \\
\hline $\begin{array}{l}\text { C } \\
\text { C SET }\end{array}$ & $\begin{array}{l}\text { CONIINUE } \\
\text { CONTINUE } \\
\text { s(1,1) }\end{array}$ & $\begin{array}{l}00003400 \\
00003470 \\
00003480 \\
00003490\end{array}$ \\
\hline
\end{tabular}


$S(1,1)=$ FLOAT(NX) * FLOAT(NY)

00003540

$Y 2=Y * Y$
$00 \mathrm{IX}=1, \mathrm{NX}$

00003550

$X=F L O A T(I X)$

$z=$ EरTाण

$5(1,2)=5(1,2)+x$

$s(2,2)=s(2,2)+x * x$

$s(3,2)=s(3,2)+X * Y$

00003560

00003570

00003580

00003590

00003600

00003610

$S(1,3)=S(1,3)+Y$.

$s(3,3)=s(3,3)+Y_{2} \quad 00003630$

$G(1)=G(1)+Z$

$G(2)=G(2)+2 * x$

00003640

00003650

$G(3)=G(3)+2 * Y \quad 00003660$

00003660

CONTINUE $\quad 00003670$

\begin{tabular}{lr}
50 CONTINUE & 00003680 \\
$C^{5}$ COMPLETE THE S ARRAY & 00003690 \\
\hline
\end{tabular}

$S(2,1)=S(1,2) \quad \ldots 00003700$

$s(3,1)=s(3,3) \quad 00003710$

$s(2,3)=s(3,2) \quad 00003720$

$\begin{array}{ll}\text { C } & 00003730\end{array}$

DO $56 K=1,3 \quad 00003750$

$\begin{array}{ll}\text { SKK }=S(K, K) & 00003760\end{array}$

$S(K, K)=1.0 \quad 00003770$

$0052 J=1,3$

S(K,J) $=5(K, J) /$ sKK

CONTINUE 00003800

$\begin{array}{ll}\text { DO } 561=1,3 & 00003810 \\ \text { SIFI-K } & 000038,56,54\end{array}$

$54 \quad$ SIK $=S(I, K) \quad 00003830$

$S(I, K)=0.0 \quad 00003840$

DO $56 \mathrm{~J}=1,3$

STI

56 CONTINUE

DO $581=1,3 \quad 00003880$

DO $57 \mathrm{~J}=1,3 \quad 00003890$

57 CUEFTI = CUEFIT \$ STI,J*GTJT 00003900

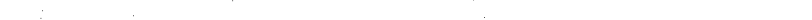

-

RETURN $\quad 00003930$

C*****************************************************************$\quad 00003950$

CTHIS SUBPOUTINE PERFORMS A DISCRETE COMPLEX FOURIER TRANSFORM ON 00003960

C A THREE DIMENSIONAL ARRAY. IT CAN BE DONE ON A 2-D ARRAY AS WELL 00003970

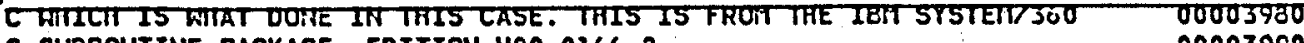

C SUBROUTIHE PACKAGE, EDITION H20-0166-2 00003990

C PARAMETERS PASSED THROUGH THE SUBROUTINE CALL ARE: M, A 3 VALUE 00004000

C VECTOR DEFINING THE SIZR OF THE INPUT ARRAY, IFSET, AN INTEGER 00004010

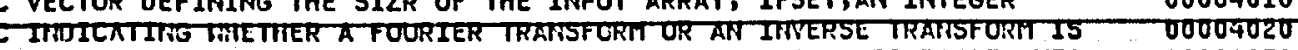

C TO BE PERFORMED, AND IFERR, AN ERROR FLAG. PARAIIETERS PASSED VIA 00004030

C COMMON BLOCKS ARE: A, A 1-D ARRAY THAT HOLDS THE DATA. IT IS LIIKED 00004040

C VIA DATAR TO BGARY IH THE MAIN PROGRAM. LHEN THE TRANSFORM IS

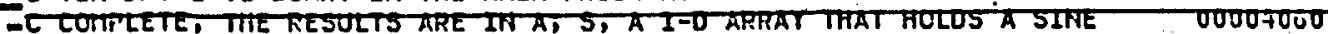

C TABLE; AHIO INV, A UORK AREA FOR THE ROUTINE. $\quad 00004070$

C SET THE DIHEHSIOH OF A TO 8*GRIDX*GRIDY

C SET THE DIMENSIOH OF S, AND OF INY TO GRIOX*GRIOY $\quad 00004090$ 
10 IF (IABS(IFSET) - 1) $900,900,12$

ROOT2 $=\operatorname{SART}(2$.

\section{0}

00004150

00004160

13 IF IIIT - MT) $14,14,13 \quad 00004180$

$\begin{array}{ll}\text { IFERR }=1 & 00004190\end{array}$

$\begin{array}{ll}\text { WRITE }(6,8) & 00004200\end{array}$

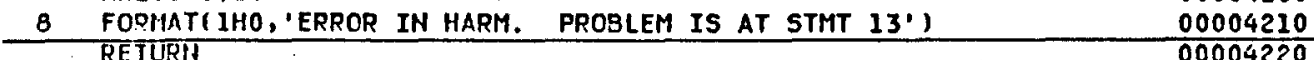

14. IFERR $=0 \quad 00004230$

$\begin{array}{ll}M I=M(1) & 00004240\end{array}$

$M 1=M(1) \quad 0004240$

$M 2=M(2) \quad 00004250$

$\begin{array}{ll}N 13=N(3) & 00004260 \\ N I=2 * * M 1 & 00004270\end{array}$

$\begin{array}{ll}N 2=2 * * 112 & 00004280\end{array}$

$\begin{array}{ll}N 3=2 * * M 3 & 00004290\end{array}$

$\begin{array}{ll}16 \text { IF (IFSET) } 18,18,20 & 00004300\end{array}$

$18 \quad N X=N 1 * N 2 * N 3 \quad 0004310$

00004320

$F N=N X=1, N X \quad 0004320$

$\begin{array}{ll}0019 I=1, N X & 00004330 \\ A(2 * I-1)=K(2 * I-1) / F H & 00004360\end{array}$

$\begin{array}{ll}A(2 * I-I)=A(2 * I-1) / F N & 00004360 \\ A(2 * I)=-A(2 * I) / F N & 00004350\end{array}$

$\begin{array}{ll}\text { COHTIHUE } & 00004360\end{array}$

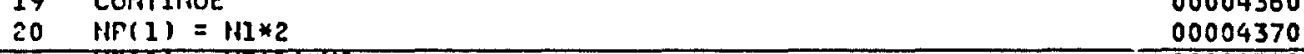

$\operatorname{TIP(2)}=\operatorname{TP}(1) \times 112$

$N P(3)=N P(2) * N 3$

NP 310 10 1,3

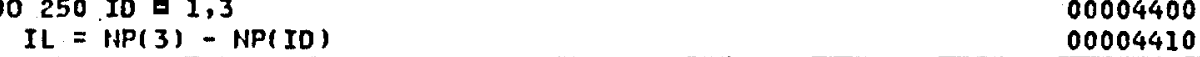

$\begin{array}{ll}I L=P I P(3)-N P(I D) & 00004410 \\ I L I=I L+I & 00004420\end{array}$

$\begin{array}{ll}M I=M(I D) & 00004430\end{array}$

IF (NI) $250,250,30 \quad 00004440$

$\begin{array}{ll}\text { IDIF }=N P(I D) & 00004450\end{array}$

RBIT = NP(IO) 00004460

MEV $=2 *(M T / 2)$

MEV (MI - MEV) $60,60,40$

IF (MI - MEV) $60,60,40 \quad 00004480$

C $\quad 00004490$

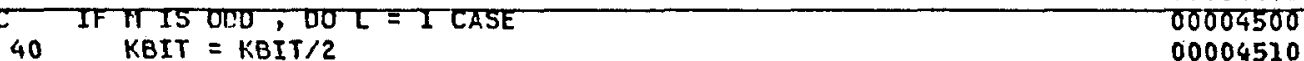

$K L=K B I T-2 \quad 00004520$

$0050 I=1, I L I, I D I F \quad 00004530$

KLAST $=K L+I$ P

$\begin{array}{ll}\text { DO } 50 \mathrm{~K}=\mathrm{I}, \mathrm{KLAST}, 2 & 00004550\end{array}$

$K D=K+K B I T \quad 00004560$

DO A STEP WITH $L=1, J=0 \quad 00004570$

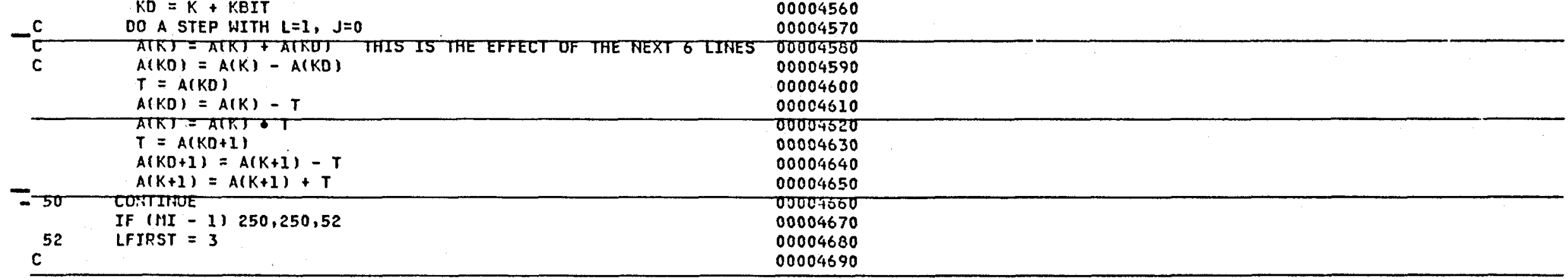




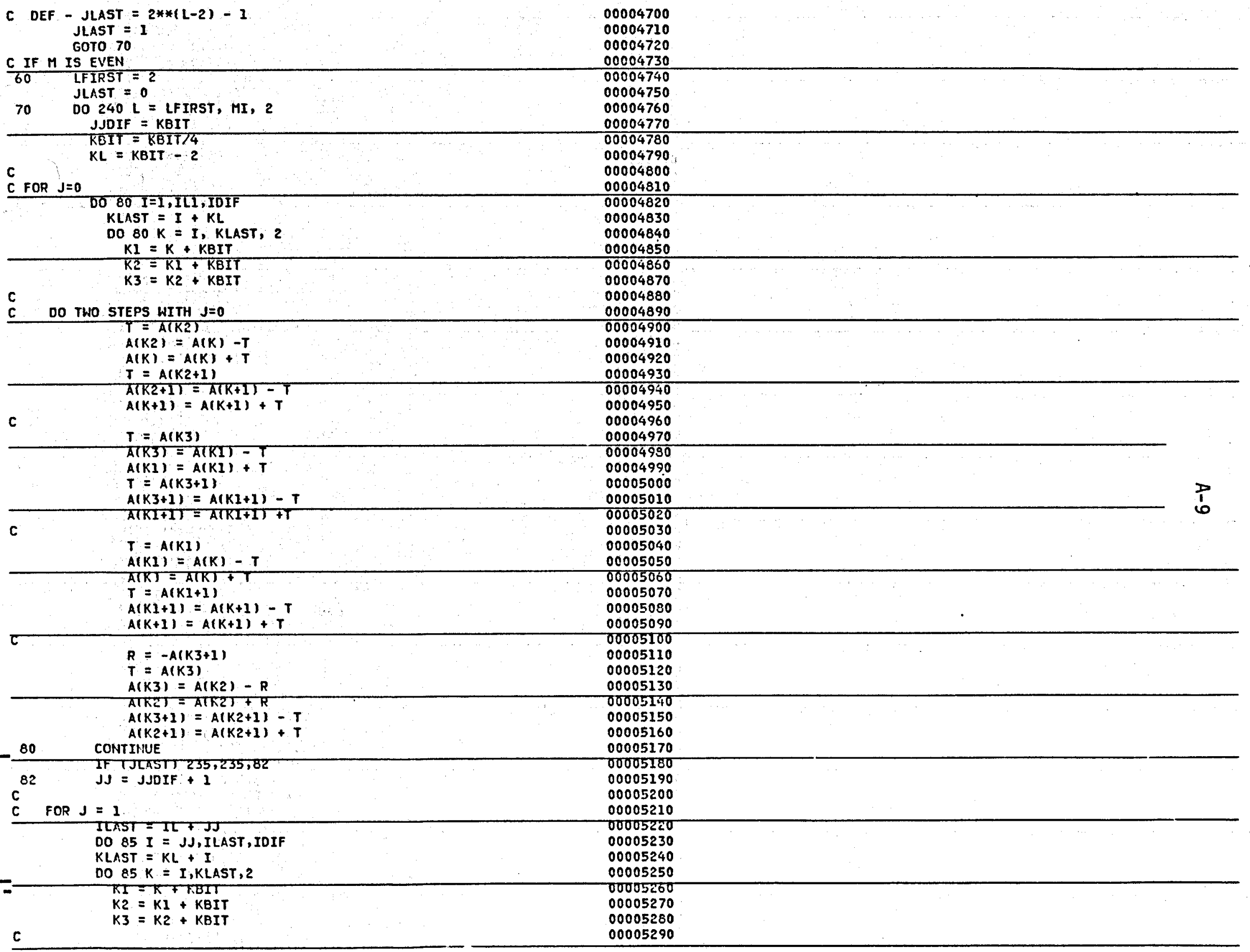


C LETTING $\omega=(1+I) /$ ROOT $2, W 3=(-1+I) / R O O T 2, W 2=1$

$A(K 2)=A(K)-R$

00005330

$A(K)=A(K)+R$

00005340

$A(K 2+1)=A(K+1)-T$

c

ATR $=A T K I)-A(K I+1)$

00005370

0005380

00005380

00005350

$\begin{array}{ll}R=-A(K 3)-A(K 3+1) & 00005400 \\ T=A(K 3)-A(K 3+1) & 00005410\end{array}$

$T=A(K 3)-A(K 3+1)$

00005420

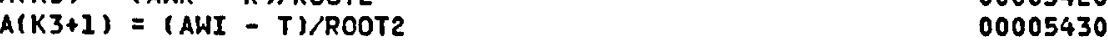

$A(K 1)=(A 4 R+R) / R O O T 2 \quad 00005440$

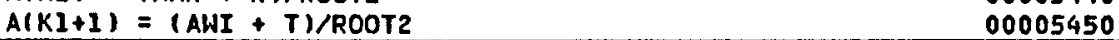

$T=A(K I) \quad 00005460$

$A(K 1)=A(K)-T \quad 1 \quad 00005470$

$A(K)=A(K)+T \quad 00005480$

$T=A(K 1+1) \quad 00005490$

$A(R I+1)=A(K+1)-T \quad 00005500$

$A(K+1)=A(K+1)+T \quad 00005510$

$\begin{array}{ll}R=-A(K 3+1) & 00005520\end{array}$

$T=A(K 3)$

A(K3) = A(K2) - R

$A(K 2)=A(K 2)+R$

$A(K 3+1)=A(K 2+1)-T$

$A(K 2+1)=A(K 2+1)+T$

85 CONIITIDE - IF $235,235,90$

$90 \quad J J=J J+J J D I F$

00005530

00005550

00005560

00005570

00005580

00005580

00005600

00005610

DO $230 \mathrm{~J}=2, \mathrm{JLAST}$

C DEF- $W=W *$ INV(J), $W 2=W * 2, W 3=W * 33$

$\begin{array}{lll}96 & I=\operatorname{INV}(J+1) & 00005640\end{array}$

$\begin{array}{lll}98 & I C=N T-1 & 00005650\end{array}$

$\begin{array}{ll}\text { WTI }=S T I C) & 00005650 \\ W(2)=S(I) & 00005660\end{array}$

$\begin{array}{ll}W(T)=S(I C) & 00005660 \\ W(2)=S(I) & 00005670\end{array}$

$\begin{array}{ll}I 2=2 * I & 00005680\end{array}$

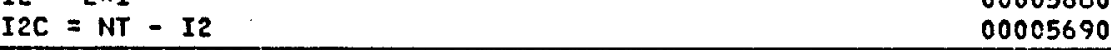

IF(I2C) $120,110,100$

$\begin{array}{ll}\text { C } 2 * I \text { IN FIRST QUADRANT } & 00005710\end{array}$

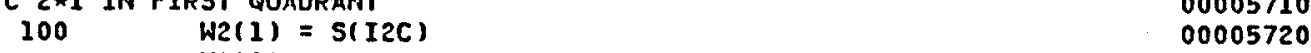

W2(1) $=S(I 2 C) \quad 00005720$

$\begin{array}{ll}W 2(2)=S(I 2) & 00005730\end{array}$

110

$\omega_{2}(1)=0.0$

$W 2(2)=1.0$

GOTO 130

00005750

00005760

00005770

$120 \quad \mathrm{IZCC}=\mathrm{I2C}+\mathrm{NT} \quad 0005780$

$\begin{array}{ll}I 2 C C=I 2 C+N T & 00005790 \\ I 2 C=-I 2 C & 00005800\end{array}$

$\begin{array}{ll}I 2 C=-I 2 C & 00005800 \\ W 2(1)=-S(I 2 C) & 00005810\end{array}$

WE $(2)=5112 C \mathrm{~T}) \quad 00305820$

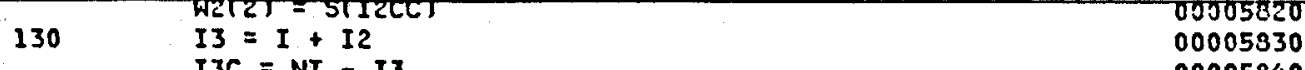

00005840

$\begin{array}{ll}\text { IFIIJC) } 160,150,140 & 00005850\end{array}$

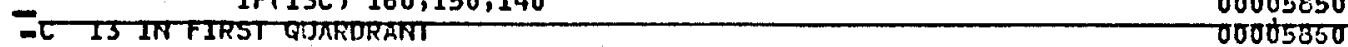

$\begin{array}{lll}140 & W 3(1)=S(I 3 C) & 00005870\end{array}$

$\begin{array}{ll}W 3(2)=S(I 3) & 00005880\end{array}$

GOTO $200 \quad 00005890$ 


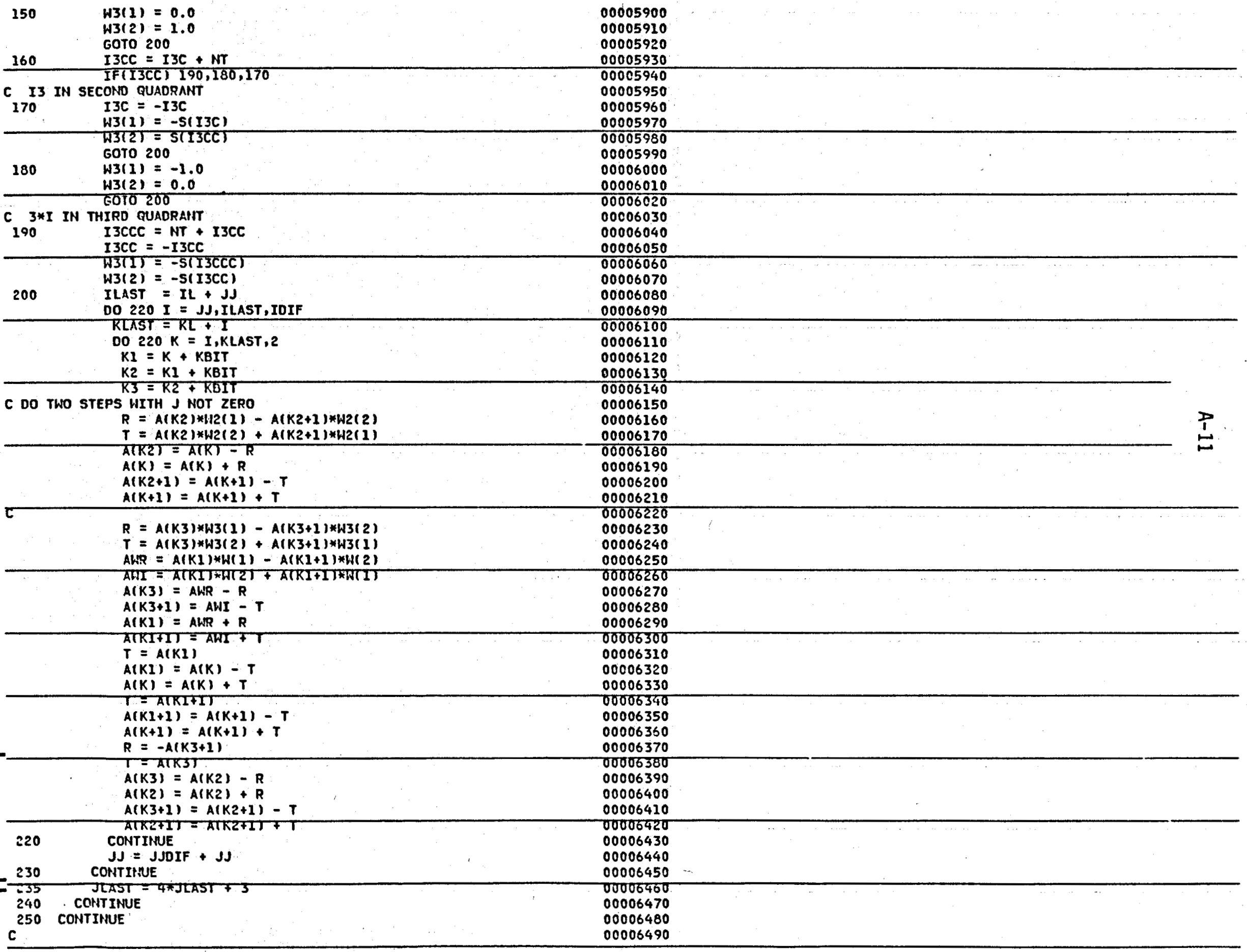


C THE COMPLEX FOURIER ARE NOW COMPUTED, BUT THEIR ADDRESSES ARE BIT-REVERSED. THE FOLLOWING PUTS THEM IN ORDER

NTSQ $=N T * N T$

$M 3 M T=M 3-M$

350 IF (MSPIT) $370,360,360$

C

M3 GREATER OR EQUAL MT

360 JGO3 = 1

N3VNT $=1$ W

MIPHA3 = NT

GOTO 380
MI LESS THAN MT

C $370 \quad 1603=2$

NSVNT $=1$

NTVHI $=$ NT $/$ N3

MINN3 $=N 3$

$380 \mathrm{JJO3}=\mathrm{NTSQ} / \mathrm{N3}$

MaMT $=M 2-M T$

450. IF (M2MT) $470,460,460$

C

460 IGO2 $=1$

N2VINT $=+12 / N T$

MINN2 $=N T$

G010 द50

C M2 LESS THAN MT

470 IGO2 $=2$

HLVHT $=1$

NTVN2 $=$ NTTN2

MIrit2 $=\mathrm{N} 2$

$490 \mathrm{JJD2}=\mathrm{NTSO} / \mathrm{N2}$

MIMT $=M 1-M T$

00006520

00006530

00006540

00006550

00006560

00006570

00006530

00006590

00006600

00006610

00006620

00006630

00006640

00006650

00006660

00006670

00006680

00006690

00006700

00006710

00006720

00006730

00006740

00006750

00006760

00006770

00006780

00006780

00006800

00006810

00006820

00006830

$\begin{array}{ll}\text { IF MI IS GREATER THAN OR EQUAL TO MT } & 00006840 \\ \text { IGOI }=1 & 00006850\end{array}$

$\begin{array}{ll}\text { IF MI IS GREATER THAN OR EQUAL TO MT } & 00006840 \\ \text { IGOI }=1 & 00006850\end{array}$

$\begin{array}{ll}\text { MIVPT }=N I T N T & 00006860 \\ \text { MINPHI }=\text { NT } & 00006870\end{array}$

$\begin{array}{ll}\text { GOTO } 580 & 00006880\end{array}$

C IF MI IS LESS THAN MT $\quad 00006890$

570 IGOI $=$ 2 200006900

$\begin{array}{ll}\text { NIVNT } 日 1 & 00006910\end{array}$

$\begin{array}{ll}\text { NTVNI }=\mathrm{NT} / \mathrm{NI} & 00006920\end{array}$

MIPHI = NI $\quad 00006930$

580 JJOI = NTSUTNI 20000640

$\begin{array}{ll}600 J J 3=1 & 00006950\end{array}$

$\begin{array}{ll}J=1 & 00006960\end{array}$

$\begin{array}{ll}\text { DO } 880 \text { JPP3 }=1, \text { N3VNT } & 00006970\end{array}$

- IPPS $=$ IPVTJJ 00006980

DO $870 \mathrm{JP3}=1$, MINH 3

GOTO $(610,620)$, IGO3 $\quad 00007000$

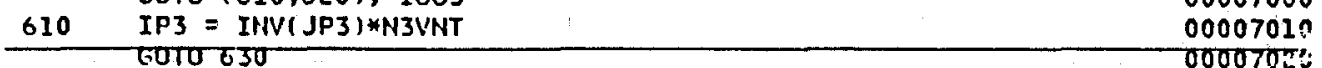

$\begin{array}{lll}620 & \text { IP3 }=\text { IHV( JP3 INTVN3 } & 00007030 \\ 630 & I 3=(I P P 3+I P 3) * N 2 & 00007040^{\circ}\end{array}$

$\begin{array}{ll}13=(I P P 3+I P 3) * N 2 & 00007040 \\ 112=I & 00007050\end{array}$

$\begin{array}{ll}\text { IPP2 }=\text { INV(JJ2) }+I 3 & 00007070 \\ \text { DO } 860 \mathrm{JP2}=1, \mathrm{MIIN12} & 00007080\end{array}$

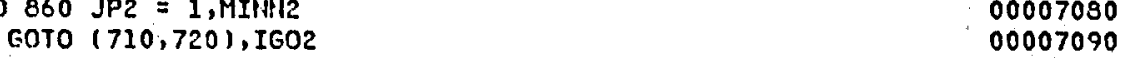




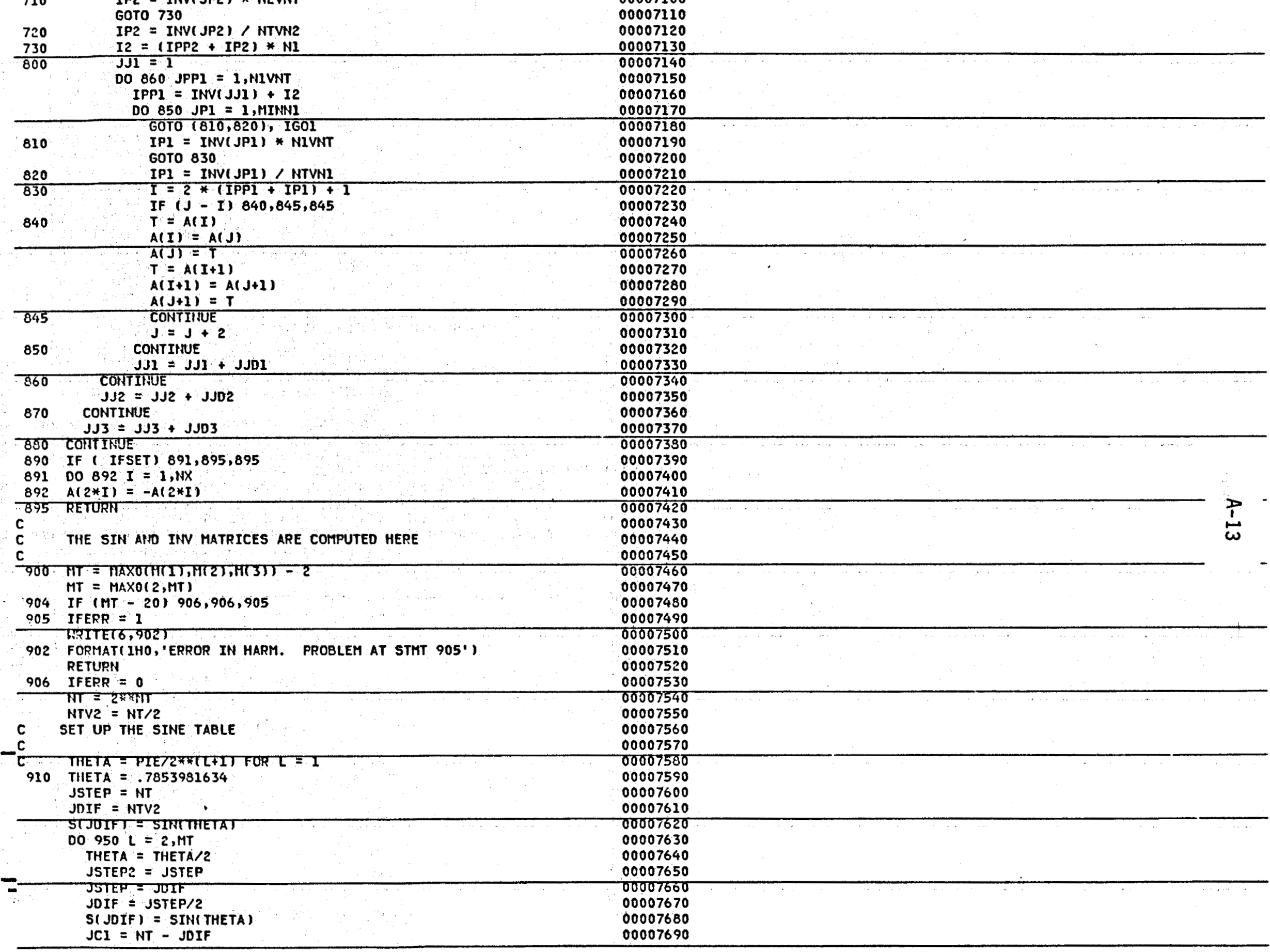




\section{$S(J C 1)=\cos ($ THETA $)$}

S( JC1) = COS(THETA

00007700

IF( JLAST - JSTEP) $950,920,920$

$S(J D)=S(J) * S(J C 1)+S(J D I F) * S(J C)$

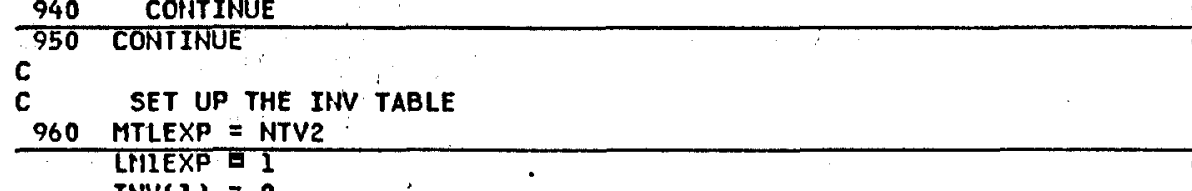

INV(1) $=0$

00007810

DO $980 \mathrm{~L}=1, \mathrm{MT}$

0007820

00007840

\begin{tabular}{ll}
$980(L=1, M T$ & 00007840 \\
INV $(L M L E X P+1)=$ MTLEXP & 00007850 \\
\hline $090-1=2, L M 1 E X P$ & 00007860
\end{tabular}

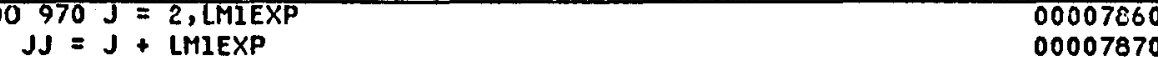

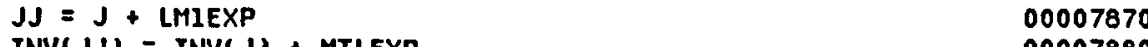

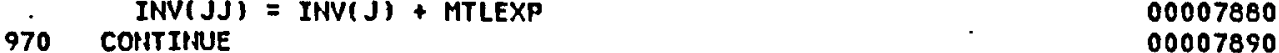

\begin{tabular}{ll}
970 COITINUE & 00007890 \\
\hline MTLEXP $=$ MTLEXP/2 & 00007900
\end{tabular}

LMLXP $=$ LMLEXP *2

980 CONTINUE

982 IF(IFSET) $12,999,12$

999 RETURN

EriD

00007910

00007920

00007930

00007950

00007960

C

THIS FILTERS A 2 DIMEIISIONAL FREQUENCY SPECTRUM USING

00007970

A PRESCRIBED WAVE NUHBER AS THE CUTOFF POINT. 00007990

FREQUENCY COMPOIIENTS HAVING A RADIAL FREGUENCY HIGHER THAN THE 00008000

FREQUEHSY SPECIFIED BY THE CUTOFF POINT ARE SET TO ZERO.

PARATIETERS ARE WX, RY SIZE OF ARRAY HOLDIIIG DATA TO FILTER ;

M, WHICH COHITAIHS INFORMATION ON SIZE OF CI FOR HARM;CUT, LEHGTH 00008030

OF CUTOFF WAVELENGTH; XOIS AND YOIS ARE LEHGTHS OF DATA MAP IN THE 00008040

$X$ AFID $Y$ DIRECTICNS. MATRIX CI IS LIHIKED TO BGARY VIA DATA2.

THIS PROCEUURE CALLS SUBROUTITE TIART TO TAKE

THE INVERSE FOURIER TRANSFORM OF THE DATA 00008070

00008090

C SET OIIENSIOT OF SIN ATID IVR TO ERIDX*GRIOY 00003100

SUBROUTIIIE FILTER(NX,NY,M,CUT, XDIS, YDIS)

00008120

COHMON /DATA2/C1 $(2,128,128) / D A T A 3 / S N(4096)$, IVR(4096) 00008130

IOP $=6$ F

NX2 $=2 * N \times$

WHIX $=$ XDIS/CUT

WHIY $=$ YDIS/CUT

WRITETIOP, I5O WTX, WNT

150 FORMAT IHO, 'CUTOFF HAVE NUMBER IS ',2F7.2)

c 150 FEGIN FILTER PROCESS

C SET YOUR PARAMETERS

DITS $=$ WITX $*$ WNT

$\mathrm{NNB2}=\mathrm{NX} / 2$

NYB2 $=N Y / 2$

NXP2 $\mathrm{NX}+2$

$=-\operatorname{MrPz}=\operatorname{Tr}+2$

NIQX = NNB2 +

C FILTER THE FIRST PROFILE

00008150

00008160

00009170

00008180

00008190

00008200

00008210

00008220

00008230

00008240

00003250

00008270

00008280

00008290 
IF. ( X.LE. WNX) GOTO 520

00008330

$I X O=0$

$510 \quad J X=$ NXP2 - IX

CII $1, J X, 11=0.0$

$\operatorname{cl}(2, j x, 1)=0.0$

$C 1(1, I X, 1)=0.0$

$C 1(2, I X, 1)=0.0$

\section{CofITINUE}

C ASSUIE THE NYQUIST FREQUENCY IS ZAPPED

C $1(1, N I Q X, 1)=0,0$

CI $(2, N I Q X, 1)=8.0$

C FILTER PROFILES 2 THROUGH NYB?

IYO $=1$

DO 570 IY $=2$, NYB2

$I Y I=I Y$

IY2 = NYP2 - IY

IF(IYO.EQ.0) GOTO 525

$Y=F L O A T(I Y-1)$

$Y 2=\gamma * Y$

If ( Y.LE.WNY) GOTO 540

IYO $=0$

525 DO $530 \mathrm{IX}=I$, NX

D $530 \mathrm{IX}=\mathrm{I}, \mathrm{NX}$

CII,IX,IYI $=0.0$

CI( $, I X, I Y 1)=0.0$
CII $I, I X, I Y 2)=0.0$

$C 1(2, I X, I Y 2)=0.0$

530 CONTINUE

GOTO 570

00008350

00008360

00008370

00008370

00008390

00008400

00008410

00003420

00008430

00008440

00008450

00008460

00008470

00008480

00008490

00008500

00008510

00003520

00008530

00008540

00008550

00008560

00008570

00008570

00008590

00008600

00008610

00003620

00008630

00008640
00008650

CONTIINUE

IXO $=1$

O $560 I X=2, \pi \times 82$

$R_{2}=X * X+Y_{2}$

IFTRE.LE.THIL GUTO 560 _ 00000700

00009670

00008680

00008690

$\mathrm{IXO}=0$

550 $J X=N X P 2-I X$

$C 1(1, J X, I Y 1)=0.0$

CIIE,JX,IYII $=0.0$

CI $(I, I X, I Y Z)=0.0$

CI( $, I X, I Y 2)=0.0$

$C 1(1 ; J X, I Y 2)=0.0$

CITाJX,IVI $=0.0$

CI $I, I X, I Y I)=0.0$

CI $(2, I X, I Y 1)=0.0$

00008700

00008710

00008720

00008730

00008740

00008750

00008760

00008770

00008770

0000878

00008790

00008300

00008310

ZEKO TITE TIGUTST FREQUEMO

00003320

CI (I, NIQX, IYI) $=0.0$

00008830

C1(2, NIQX,IY1) $=0.0$

CI 1 , NIQX,IY2) $=0.0$

570 COUTENIGNITLI $=0.0$

c ZERO THE FOLDING PROFILE

00008340

00008850

00008800

00003870

00008380

IF(IYO.EQ.O) GOTO 580 
CALL HARMIM, -2 , IFMISS) 00008940

IF ( IFMISS.EQ.0) GOTO $590 \quad 00008950$

$\begin{array}{ll}\text { WRITE }(6,585) & 00008960\end{array}$ WRITE $(6,586) \quad 00008970$

SUBROUTTNE HARM RETURNED AN ERROR CODE WHEN CALLED 00000898

585 FORMAT (1HO, 'SUBROUT

586 FORMAT (IH , ' BY SUBROUTINE FILTER. EXECUTION HAS HALTED')

590 CONTINUE

$$
\text { RETU.RN }
$$

C

END

00009000

00009020

00009030

00009040

\begin{tabular}{ll}
$C * * * * * * * * * * * * * * * * * * * * * * * * * * * * * * * * * * * * * * * * * * * * * * * * * * * * * * * * * * *$ & 00009050 \\
\hline$C$ & 00009060
\end{tabular}

C THIS SURROUTINE EXTRACTS THE DATA FROM THE CENTER OF THE

FOLDED AHI TAPERED MATRIX $\quad 00009080$

C SET DIFERSIOTS OF SIGRIO TO GRIOX,GRTDY

C SET DIMENSIOHS OF BIGRID TO $2,2 *$ GRIDX,2*GRIDY $\quad 00009100$

SUBROUTINE STRIP(NX,NY)

COIRION/DATA1/SMGRID $(64,64) / 0 A T A 2 / B I G R I D(2,128,128)$

C 00009140

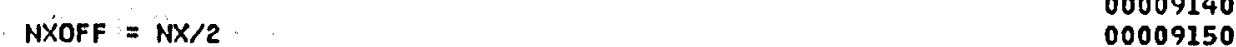

$\begin{array}{ll}\text { NYOFF }=\text { NY/2 } & 00009160\end{array}$

C STRIP FOLDED AH:D TAPERED PORTION FROM THE BIGGRID $\quad 00009170$

700090 IY $=1$ IIN 00009180

$\begin{array}{ll}J Y=I Y+N Y O F F & 00009190\end{array}$

DO 80 IX $=1, \mathrm{NX} \quad 00009200$

$\mathrm{JX}=\mathrm{IX}+\mathrm{NXOFF} \quad 00009210$

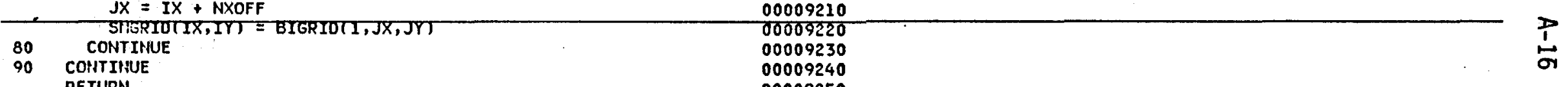

RETUPN $\quad 00009240$

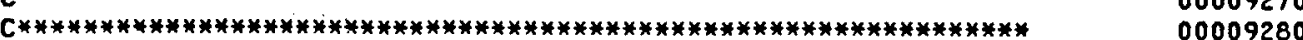

C THIS ROUIIIE RETURTIS THE FIRST UTDER IRERD TO THE OATA THAT 0009290

C WAS REMOVED DURIHG THE FFTSET ROUTINE $\quad 00009310$

$\begin{array}{ll}\text { C } & \\ \text { C SET DIMEHSIOHS OF ARRAY TO GRIDX, GRIOY } & 00009320 \\ \end{array}$

STE:TUUTIFE RETRENTIRETINX, IIT

COMIION/OATAI/ARRAY $(64,64) \quad 00009350$

DIMENSION TREN(3) 00009360

$\begin{array}{ll}C & 00009370\end{array}$

$\begin{array}{ll}Y T=F L O A T(I Y) & 00009380\end{array}$

00009390

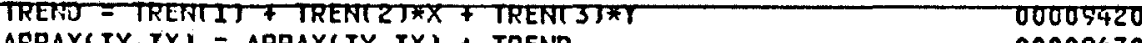

IX,IY $=$ ARRAY $(I X, I Y)+$ TREND

\begin{tabular}{llr}
60 & COHIIRIUE & 00009440 \\
70 & COHIIIUE & 00009450 \\
\hline RETURN & 00009400
\end{tabular}


B-i

Appendix B

FORTRAN Program SPECTRA 
**** TSO FOREGROUND HAROCOPY ****

DSNAME = NPGG490. SPECTRA. PRG

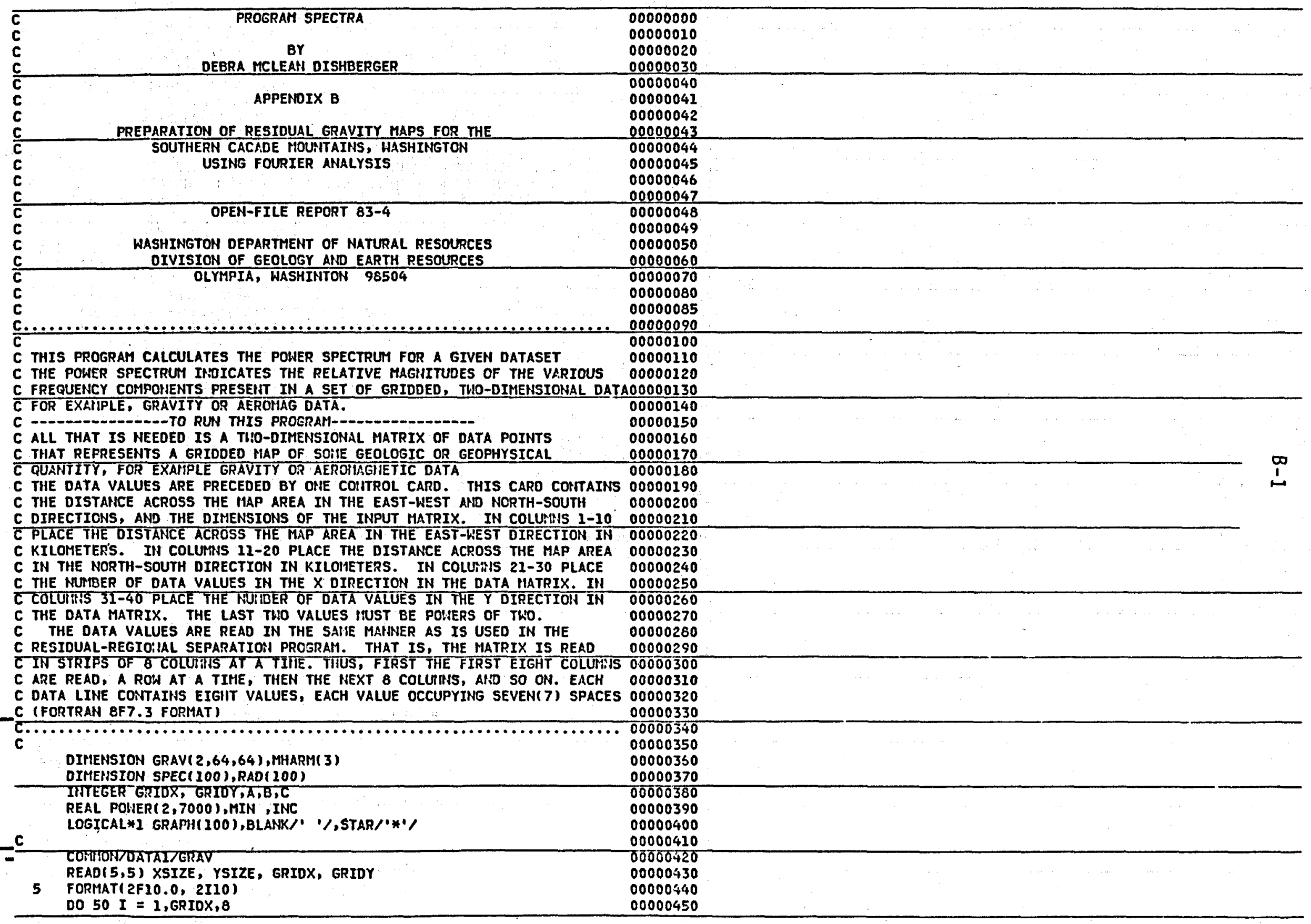




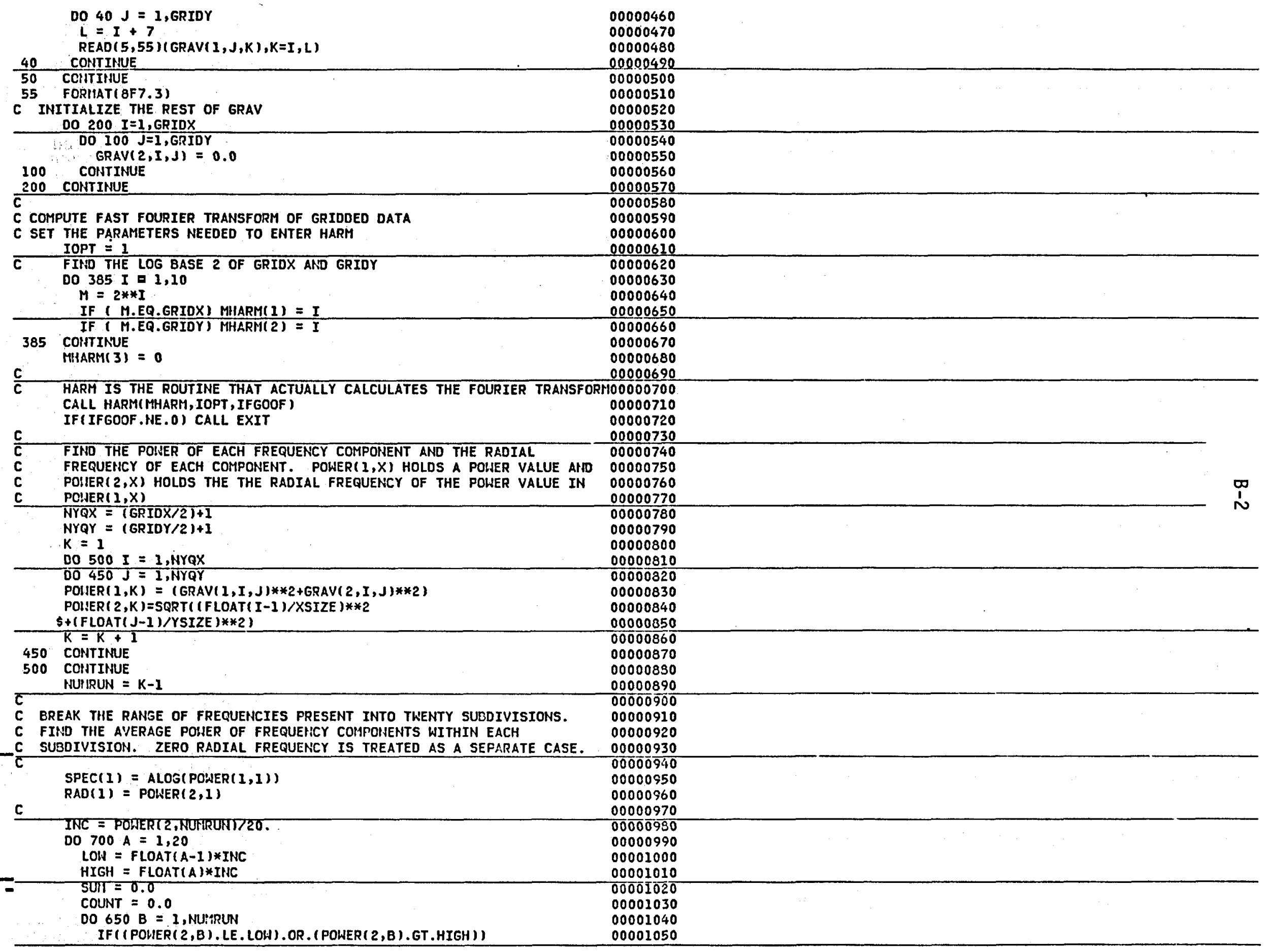


GOTO 650

SUM $=$ SUM + POWER $(I, B)$

00001060

COUNT $=$ COUNT +1

650 COHIIIUUE

00001080
00001090

IF (SUM.GT.0.0) G0T0 660

$\operatorname{SPEC}(A+1)=0.0$

GOTO 670

660 SPEC $(A+1)=A L O G(S U M / C O U N T)$

$670 \quad \operatorname{RAD}(A+1)=$ (FLOAT(A)-.5) $*$ INC

c 700

CONT IHUE

WRITE $(6,900)$

900 FORMAT(IHO,' RADIAL FREQUENCY',10X,'POWER')

DO $950 I=1,21$

WRITE $(6,975)$ RAD(I ), SPECI I )

$\frac{950 \text { CONTINUE }}{975 \text { FORMATIIH }, 10 X, F 6,3,10 X, F 7.2)}$

$c^{975}$

C MAKE A PLOT OF POWER SPECTRUM

WRITE $(6,990)$

990 FORHATIIH-, 'PLOT OF POWER SPECTRUM')

DO $1000 \mathrm{~N}=1,100$

GRAPH(N) = BLANK

1000 CONTINUE

C $\quad N=\operatorname{IFIX(SPEC(1)*10,)}$

GRAPH $(N)=$ STAR

WRITE $(6,1200) R A D(1)$, GRAPH

$\operatorname{GRAPH}(N)=$ BLAIKK

c

DO $1100 I=2,21$

$N=\operatorname{IFIX(SPEC}(I) * 10$.

GRAPH(N) = STAR

IRRITE $(6,1200)$ RAD(I), GRAPH

WRITE $(6,1250)$

GRAFII(N) = BLANK

1100 CONTINUE

1200 FORIIAT (1H, ,F6.3,100A1)

1250 FORMATI IH )

STOP

c

C********************************************************1

C SUDROUTINE PRIIATINX,NY, MIAT)

COIIION/DATA1/SHIGRID $(64,64) / D A T A 2 / B G G R I D(2,128,128)$

00001100

00001110

00001120

00001130

00001130

00001140

00001160

00001170

00001180

00001190

00001200

00001210

00001220

00001230

00001240

00001250

00001260

00001270

00001280

00001280

00001290

00001300

00001310

00001320

00001330

00001340

00001340

00001360

00001370

00001380

00001390

00001400

00001410

00001420
00001430

00001440

00001450

00001460

00001470

0001470

00001480

00001490

00001500

00001510

00001520

THIS ROUTINE PRINTS OUT A MATRIX, EITHER THE ORIGINAL DATA MATRIX O0001530

OQ THE FOLDEO ATIO TAEERED HATPIX PARAHETERS APE: IX, THE X 00001540

DIIENSION; NY, THE Y DIMENSTCN; AND MAT, LHICH SPECIFIES IF 00001550

THE LARGE OR SMALL MATRIX IS TO BE PRINTED 00001550

00001570

00001580

$00100 \mathrm{~K}=1, \mathrm{NY}, 16$

$L=K+15$

DO $50 I=1, H X$

IF (MAT.EQ.1) GOTO 25

$\begin{array}{ll}\text { WRITET6,150 (SITGRIDTI,J),J }=K, L) & 00001620 \\ \text { GOTO } 50 & 00001630\end{array}$

$\begin{array}{ll}\text { C GOTO 50 } & 00001630 \\ \text { LIRITE }(6,150) \text { (BGGRIO(I,I,J),J=K,L) } & 00001640\end{array}$

C5O CONTINUE 
C***************************************************************** CTHIS SUBROUTIIIE. PERFORMS A DISCRETE COIPLEX FOURIER TRANSFORM ON C A THIREE DIMENSIOHIAL ARRAY. IT CAN BE DOHE ON A 2-D ARRAY AS WELL C HIIICH IS WIIAT DONE IN THIS CASE. THIS IS FROM THE IBM SYSTEM/360 C SUBROUTINE PACKAGE, EOITION H20-0166-2

SUBROUTINE HARM(M, IFSET, IFERR)

COIIION/DATA1/A( 32768 )/DATA3/S(4096), INV(4096)

00001760

DIMENSION $N(3), M(3), N P(3), W(2)$, W2 $(2), W 3(2)$

00001790

00001810

10 IF (IABSI IFSET) - $11900,900,12$

12 MTT $=\operatorname{MAXO}(M(1), M(2), M(3))-2$

00001820

ROOT2 = SQRT(2.

00001830

IF (MIT - MT) $14,14,13$

13 IFERR $=1$

8 FCRIATIIHO, 'ERROR IN HARM. PROBLEM IS AT STMT 13') RETURH

14 IFERR $=0$

$M 1=M(1)$

00001840

00001850

00001860

00001870

00001880

00001890

$M 2=M(2)$

00001900

$M 3=M(3)$

$N 1=2 * * N 1$

$\mathrm{N2}=2 * 3: 112$

N3 $=2 * * 113$

16 IF (IFSET) $18,18,20$

$18 N X=N 1 * N 2 * N 3$

$F N=N X$

DO $191=1, N X$

00001910

00001920

00001930

00001940

00001950

00001960

00001970

00001930

00001930

$\begin{array}{ll}A(2 * I-I)=A(2 * I-I) / F N & 00002000 \\ A(2 * I) D-A(2 * I) / F N & 00002010\end{array}$

$\begin{array}{ll}A(2 * I-I)=A(2 * I-I) / F N & 00002000 \\ A(2 * I) D-A(2 * I) / F N & 00002010\end{array}$

I9 CONTIRIUE

$20 \quad N P(1)=N I * 2$

$N P(2)=N P(1) \times N 2$

$N P(3)=N P(2) * N 3$

00250 IO $=1,3$

IL $=N P(3)-N P(I D)$

00002030

(1)

00002040

00002050

00002060

00002070

$I L I=I L+I$

$M I=M(I D)$

30 IF (NII) $250,250,30$

00002080

00002100

$30 \quad$ IDIF $=$ HP(ID)

KBIT $=N P(I D)$

MEV $=2 *(M I / 2)$

$-\frac{\text { MEV }=2 *(M I / 2)}{I F(M I-N E V) 60,60,40}$

00002120

00002130

00002140

00002150

00002160

C IF M IS ODD, DO L = 1 CASE

$40 \quad K B I T=K B I T / 2$

DO $50 I=1, I L 1$, IOIF

$K L A S T=K L+I$

DO $50 K=I, K L A S T, 2$
CD $=K+K E I T$
DO A STEP WITH LI, J $J=0$

$C \quad A(K)=A(K)+A(K D)$ THIS IS THE EFFECT OF THE NEXT 6 LINES

00002170

00002180

00002190

00002200

$0000 \div 20$

00002220

00002230

$A(K D)=A(K)-A(K D)$ 


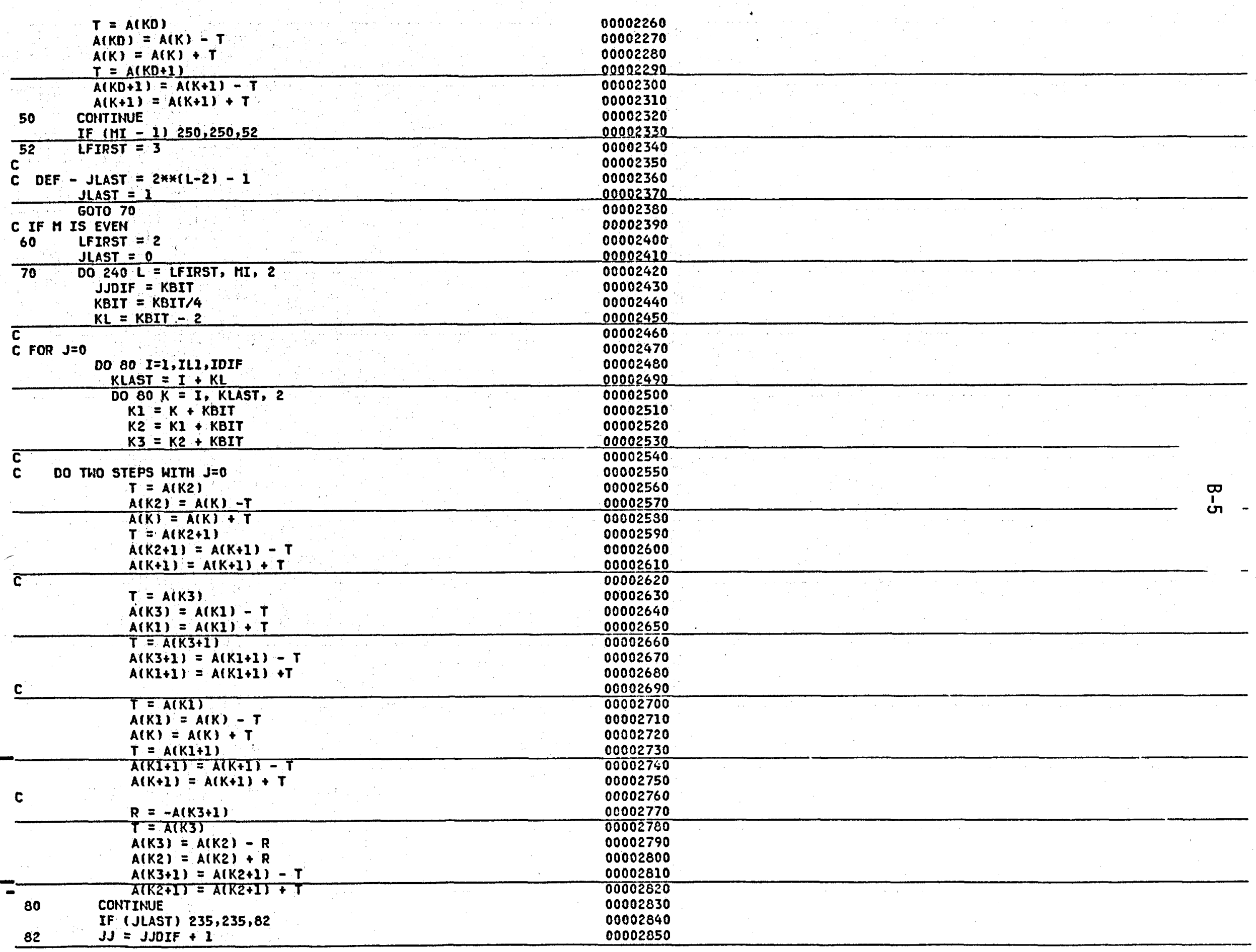


$K L A S T=K L+I$

00002880

00 O5 $K=I$ L +1

$K 1=K+K B I T$

$K 2=K 1+K B I T$
$K 3=K 2+K B I T$

C LETTING $W=(1+I) /$ ROOT2, $W 3=(-1+I) /$ ROOT,$W 2=1$

00002890

00002900

00002910

00002920

00002930

00002940

00002950

00002960

$R=-A(K 2+1)$

$T=A(K 2)$

$A(K 2)=A(K)-R$

$A(K)=A(K)+R$

$A(K 2+1)=A(K+1)-T$

00002970

00002980

00002990

00003000

00003010

00003020

00003030

$A U R=A(K 1)-A(K 1+1)$

$A W I=A(K 1+1)+A(K 1)$

$R=-A(K 3)-A(K 3+1)$

$T=A(K 3)-A(K 3+1$

$A(K 3)=(A W R-R) / R O O T 2$

$A(K 3+1)=($ AWI $-T) /$ POOT2

$A(K 1)=($ ALR + R) $/$ ROOT2

$A(K 1+1)=(A W I+T 1 / R O O T 2$

00003040

00003050

00003060

0000307.0

00003080

00003090

$T=A(K 1)$

$A(K I)=A(K)=T \quad 00003120$

$A(K)=A(K)+T$

$T=A(K I+1)$

00003140

00003150

00003160

\begin{tabular}{ll}
$A(K+1)=A(K+1)+T$ & 00003160 \\
\hline & 00003170
\end{tabular}

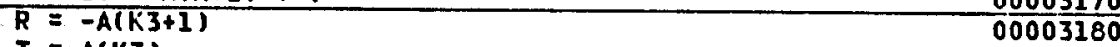

$\begin{array}{ll}T=A(K 3) & 00003190\end{array}$

$A(K 3)=A(K 2)-R \quad 00003200$

$A(K 2)=A(K 2)+R \quad 00003210$

$A(\bar{K}+1)=A(K 2+1)-T \quad 00003220$

$A(K 2+1)=A(K 2+1)+T$

CONTIHUE

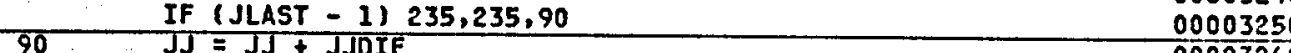

$\begin{array}{ll}\mathrm{C} & 00003260\end{array}$

DO $230 \mathrm{~J}=2, J L A S T \quad 00003270$

C DEF-W=W*INV $(J)$, W2 $=W * W * W 3=W * 3 * 3$

$96 \quad I=I$ IIV $(J+1)$

98 IC $=N T-1 \quad 00003310$

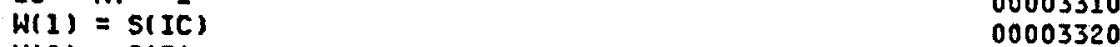

$\begin{array}{ll}W(2)=S(I C) & 00003320 \\ W(2)=S(I) & 00003330\end{array}$

\begin{tabular}{ll} 
W(2) & 00003330 \\
\hline $12=2 * I$ & 00003340
\end{tabular}

$I 2 C=N T-I 2 \quad 00003350$

IF(I2C) $120,110,100$

C 2*I IN FIRST CUADRANT 00003330

$\begin{array}{ll}c & 00003370\end{array}$

$\begin{array}{ll}W 2(2)=S(I 2) & 0000338 \\ & 00003390\end{array}$

$\begin{array}{ll}\text { GOTO } 130 & 00003390 \\ \text { W } & 00003400\end{array}$

$\begin{array}{lll}110 & \text { W2 }(1)=0.0 & 00003400 \\ & & 0003410\end{array}$

Wह $(2)=1.0$

C 2*I IN SECOND QUADRANT $\quad 00003440$

$\begin{array}{ll}120 \quad I 2 C C=I 2 C+N T & 00003450\end{array}$




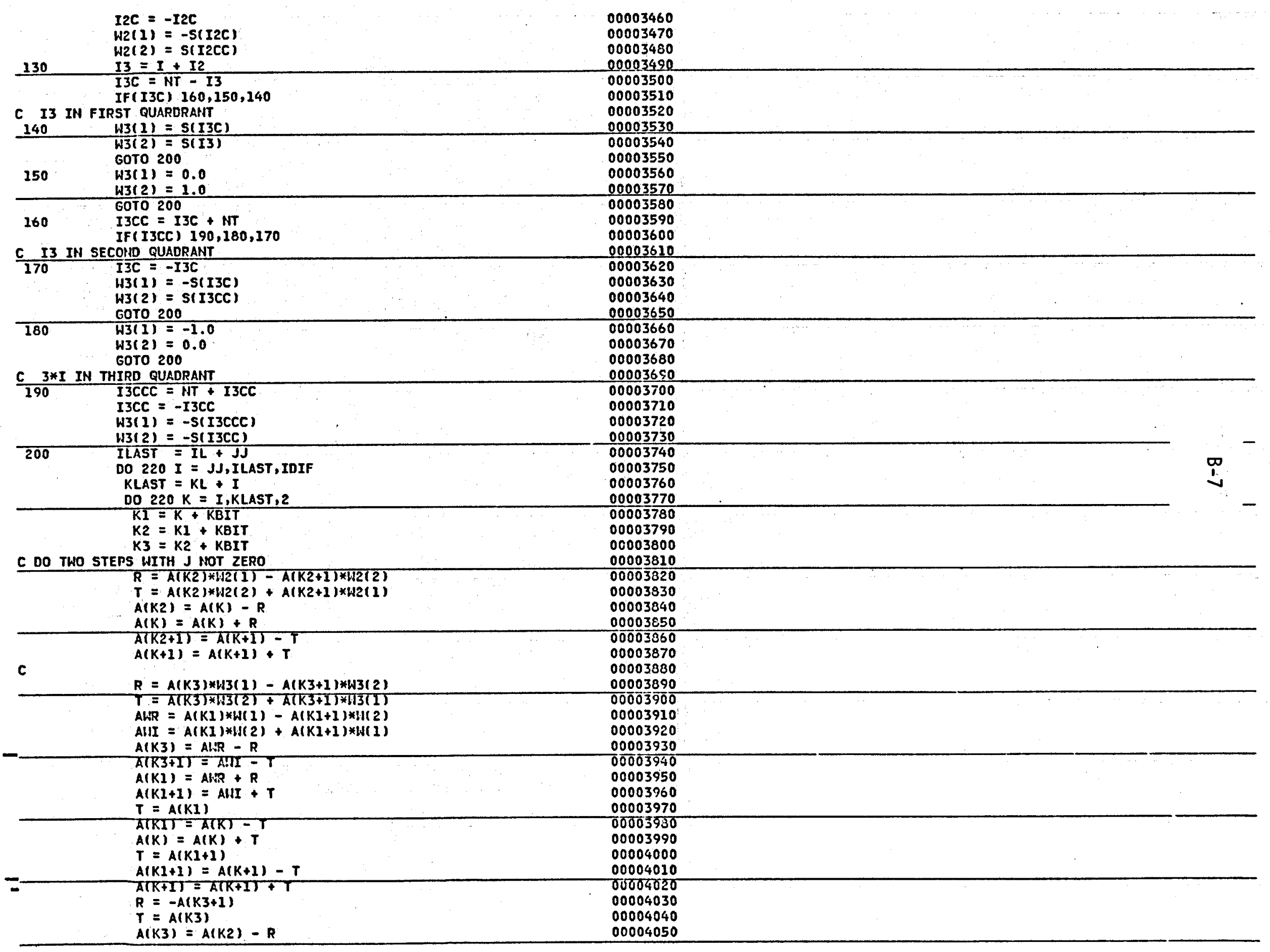




\begin{tabular}{|c|c|c|}
\hline 220 & $\begin{array}{l}A(K 2)=A(K 2)+R \\
A(K 3+1)=A(K 2+1)-T \\
A(K 2+1)=A(K 2+1)+T \\
\text { COHITINUE }\end{array}$ & $\begin{array}{l}00004060 \\
00004070 \\
00004060 \\
00004090\end{array}$ \\
\hline $\begin{array}{l}230 \\
235 \\
240 \\
\end{array}$ & $\begin{array}{l}\text { JJ }=\text { JJOIF }+\mathrm{JJ} \\
\text { CONTINUE } \\
\text { JLAST }=4 * \text { JLAST }+3 \\
\text { COHITIHUE }\end{array}$ & $\begin{array}{l}00004100 \\
00004110 \\
00004120 \\
0,004130\end{array}$ \\
\hline $\begin{array}{l}250 \\
c \\
c\end{array}$ & $\begin{array}{l}\text { COHT IFIUE } \\
\text { THE COMPLEX FOURIER ARE NOW CONIPUTED, BUT THEIR ADDRESSES } \\
\text { ARE BIT-REVERSED. THE FOLLOWIHG PUTS THEM IN ORDER }\end{array}$ & $\begin{array}{l}00004140 \\
00004150 \\
00004160 \\
00004170\end{array}$ \\
\hline $\mathrm{C}^{350}$ & $\begin{array}{l}\text { NTSQ }=N \text { NT }^{*} \text { NT } \\
\text { MBHT }=\text { H3 }-M T \\
\text { IF (M3HT) } 370,360,360\end{array}$ & $\begin{array}{l}00004180 \\
00004190 \\
00004200 \\
00004210 \\
\end{array}$ \\
\hline 360 & $\begin{array}{l}\text { M3 GREATER OR EQUAL MT } \\
\text { IGO3 }=1 \\
\text { N3VNT }=\mathrm{N3} / \mathrm{NT} \\
\text { MINH } 3=\mathrm{NT}\end{array}$ & $\begin{array}{l}00004220 \\
00004230 \\
00004240 \\
00004250 \\
\end{array}$ \\
\hline$C_{370}$ & $\begin{array}{l}\text { GOTO } 380 \\
M 3 \text { LESS THAN MT } \\
\text { IGO3 }=2 \\
\text { N3VHT }=1\end{array}$ & $\begin{array}{l}00004260 \\
00004270 \\
00004280 \\
00004290 \\
\end{array}$ \\
\hline 380 & $\begin{array}{l}\text { NTVN3 }=N T / N 3 \\
M I H N 3=N 3 \\
\text { JJO3 }=\text { NTSQ/N3 } \\
\text { M2H1T }=\text { M2 - HTT }\end{array}$ & $\begin{array}{l}.00004300 \\
00004310 \\
00004320 \\
00004330 \\
\end{array}$ \\
\hline $\begin{array}{l}450 \\
c^{460} \\
\end{array}$ & $\begin{array}{l}\text { IF (II2MT) } 470,460,460 \\
\text { M2 GREATER OR EQUAL MT } \\
\text { IGO2 = } 1\end{array}$ & $\begin{array}{l}00004340 \\
00004350 \\
00004360 \\
00004370\end{array}$ \\
\hline C & $\begin{array}{l}\text { NâVNT }=\text { N2/NT } \\
\text { MINH! }=\text { NT } \\
\text { GOTO } 480 \\
\text { M2 LESS THAN MT }\end{array}$ & $\begin{array}{l}00004380 \\
00004390 \\
00004400 \\
00004410\end{array}$ \\
\hline 470 & $\begin{array}{l}\text { IGO2 }=2 \\
\text { N2VHHT }=1 \\
\text { NTVIH2 }=\text { NT/N2 } \\
\text { MINH2 = N2 }\end{array}$ & $\begin{array}{l}00004420 \\
00004430 \\
00004440 \\
00004450\end{array}$ \\
\hline$c^{550}$ & $\begin{array}{l}J J 2=\text { NTSQTN2 } \\
\text { MIHI }=M L-M T \\
\text { IF(MIMT) } 570,560,560\end{array}$ & $\begin{array}{l}00004460 \\
00004470 \\
00004480 \\
00004490\end{array}$ \\
\hline 560 & $\begin{array}{l}\text { IF HI IS GREATER THLN OR EQUAL TO NT } \\
\text { IGOI = I } \\
\text { NIVNT = NI/NT } \\
\text { MIINII =NT } \\
\text { GOTO } 5 \text { SO }\end{array}$ & $\begin{array}{l}00 \overline{004500} \\
00004510 \\
00004520 \\
00004530\end{array}$ \\
\hline$C_{570}$ & $\begin{array}{l}\text { IF MI IS LESS THAN HT } \\
\text { IGOI }=2 \\
\text { NIVNT }=1\end{array}$ & $\begin{array}{l}00004540 \\
00004550 \\
00004560 \\
00004570\end{array}$ \\
\hline $\begin{array}{r}580 \\
600 \\
\end{array}$ & $\begin{array}{l}\text { NTVHI }=\text { NT/NI } \\
\text { MINNN1 }=\text { NI } \\
\text { JJDI }=\text { NTSQ/N1 } \\
\text { JJ3 }=1\end{array}$ & $\begin{array}{l}00004560 \\
00004590 \\
00004600 \\
00004610\end{array}$ \\
\hline 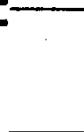 & $\begin{array}{l}\text { J } \\
\text { DO } 890 \text { JPP3 }=1 \text {,N3VNT } \\
\text { IPP3 = IIV(JJ3) } \\
\text { DO } 870 \text { JP3 }=1, \text { HINH3 }\end{array}$ & $\begin{array}{l}00004620 \\
00004630 \\
00064540 \\
00004650\end{array}$ \\
\hline
\end{tabular}


GOTO $(610,620)$, IGO3

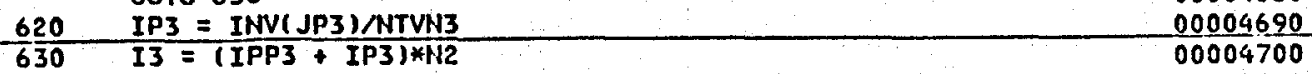

$\begin{array}{lll}700 \quad J J 2 & =1 & 00004710\end{array}$

DO 870 JPP2 $=1$, N2VNT $\quad 00004720$

$I P P 2=I N V(J J 2)+13$

DO $860 \mathrm{JP2}=1$, MINN2 $\quad 00004740$

60T0 $(710,720)$, IGO2 $\quad 00004750$

$\begin{array}{lll}710 & \text { IP2 }=\text { INV( JP2 ) * N2VWT } & 00004760 \\ & \text { GOTO } 730 & 00004770\end{array}$

\begin{tabular}{lll} 
& GOTO 730 & 00004770 \\
\hline 720 & IP2 $=$ INV(JP2) / NTVN2 & 00004780
\end{tabular}

$\begin{array}{ll}I P 2=I N V(J P 2) / \text { NTVN2 } & 00004780 \\ I 2=(I P P 2+I P 2) * N 1 & 00004790\end{array}$

00004790
00004800

DO 860 JPP1 $=1$, NIVNT $\quad 00004810$

IPP1 - IMV(JJI) IR

IPPI $=12010+12$

00004810

00004820

00004840

$\begin{array}{ll}\text { GOTO }(810,820), \text { IGOI } & 00004840 \\ \text { IPI }=\text { INV(JPI)* NIVNT } & 00004850 \\ \text { GOTO 830 } & 00004860 \\ \text { IPI }=\text { INV( JPI) / NTVHI } & 00004870\end{array}$

$\begin{array}{lll}810 & \text { GOTO } 830 & 0004860 \\ 820 & \text { IP1 }=\text { INV(JPI) / NTVH1 } & 00004870 \\ 830 & I=2 *(I P P I+I P 1)+1 & 00004880\end{array}$

$830 \quad I=2 *$ (IPPI + IPI) $+1 \quad 00004880$

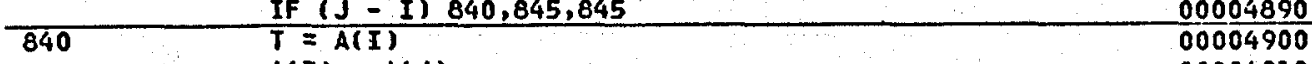

$A(I)=A(J) \quad 00004910$

$A(J)=T \quad 00004920$

$T=A(I+1) \quad 00004930$

$A(I+1)=A(J+1) \quad-00004940$

$A(J+1:=T$

AC $J+1:=T$

\begin{tabular}{rr} 
CONTINUE & 00004960 \\
$1=J+2$ & 00004970 \\
\hline
\end{tabular}

\begin{tabular}{ll}
\hline 850 & CONIINUE \\
JJ1 $=$ JJI + JJD1 & 00004980 \\
& 00004990
\end{tabular}

$\begin{array}{ll}860 \quad \text { CONTIHNE }=J J 1+J J D 1 & 00004990 \\ & 00005000\end{array}$

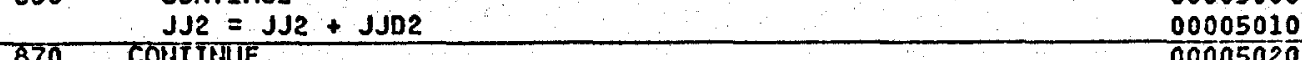

00005020

$J J 3=J 13+J J 03 \cdots 00005030$

00005040

890 IF (IFSET) $891,895,895 \quad 00005050$

$89100892 \mathrm{Y}=1, \mathrm{NX} \quad 00005060$

$892 A(2 * I)=-A(2 * I) \quad 00005070$

895 RETURN $\quad 00005080$

$\begin{array}{ll}C & 00005090\end{array}$

C THE SIH AND ITV HATRICES ARE COMPUTED HERE 00005100

00005110

$M T=M A X 012, M T) \quad 00005130$

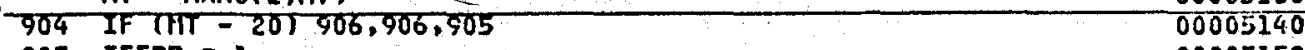

$\begin{array}{ll}905 \text { IFERR }=1 & 00005150\end{array}$

URITE(6,902)

902 FCRMAT(1HO, 'ERROR IN HARM. PROBLEM AT STMT 905')

902 FETURT 00005180

$\begin{array}{ll}906 \text { IFERR }=0 & 00005190\end{array}$

NT = 2**HT $\quad 00005200$

$\begin{array}{ll}\text { HTV2 }=N T / 2 & 00005210\end{array}$

$\begin{array}{lll}-C & \text { SET UW THE SINE TABLE } & 0000 E 220 \\ C & & 00005230\end{array}$

$\begin{array}{ll}\text { C } & 00005230\end{array}$

910 THETA $=.7853981634$ POR $L=$

910 THETA $=.7853981634 .00005250$




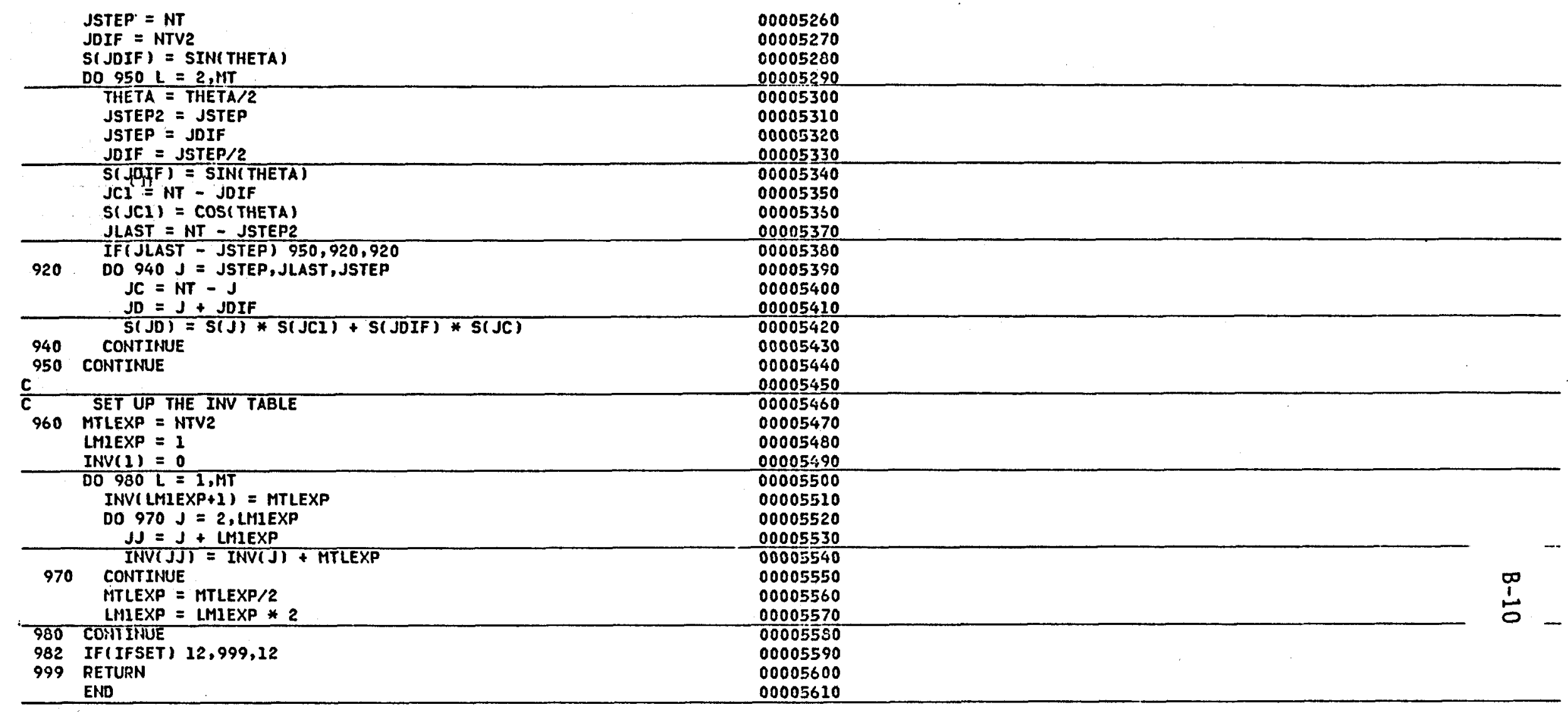



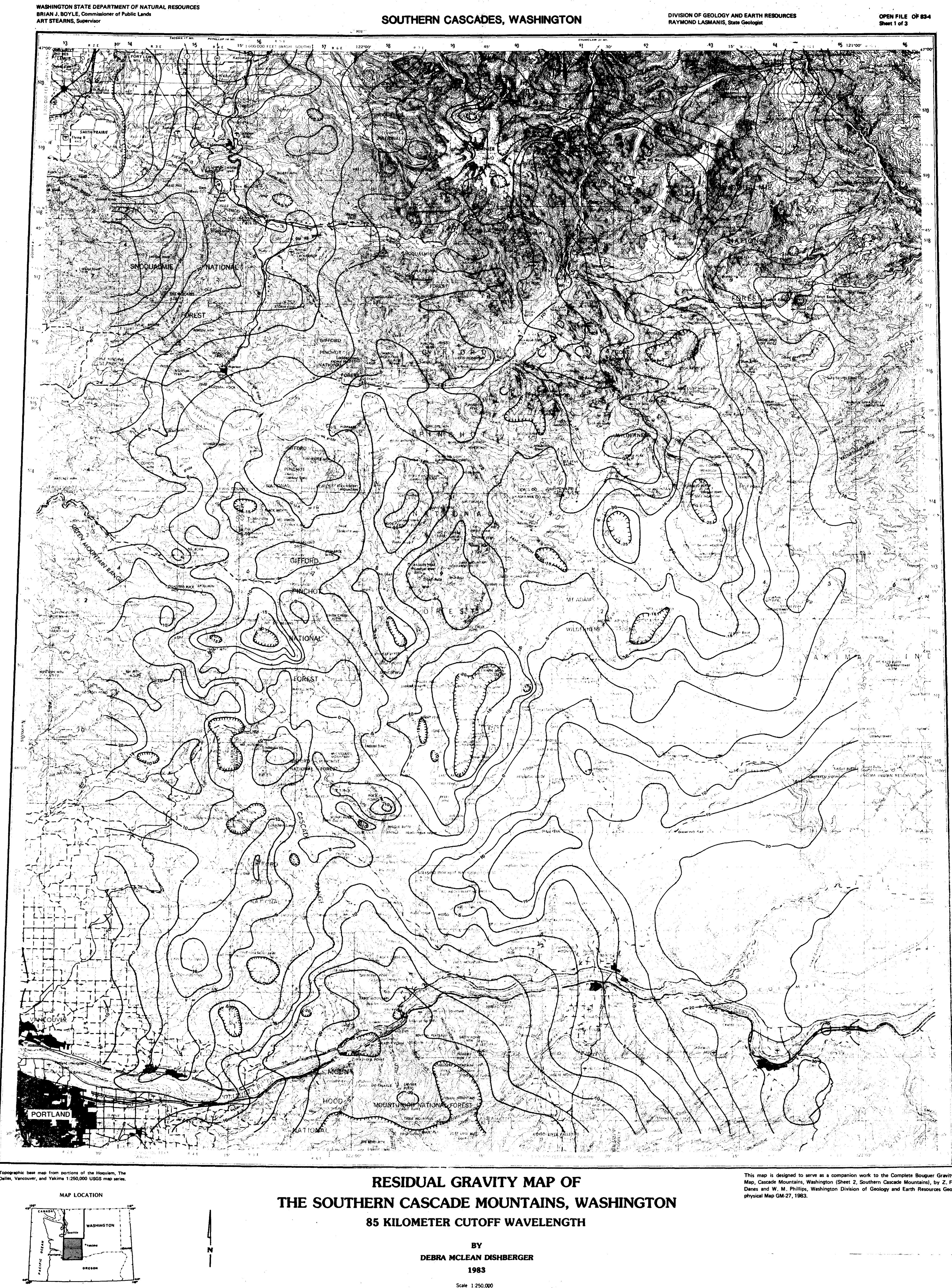

RESIDUAL GRAVITY MAP OF

THE SOUTHERN CASCADE MOUNTAINS, WASHINGTON

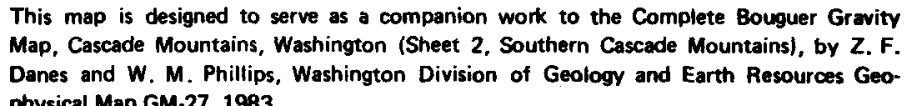
85 KILOMETER CUTOFF WAVELENGTH

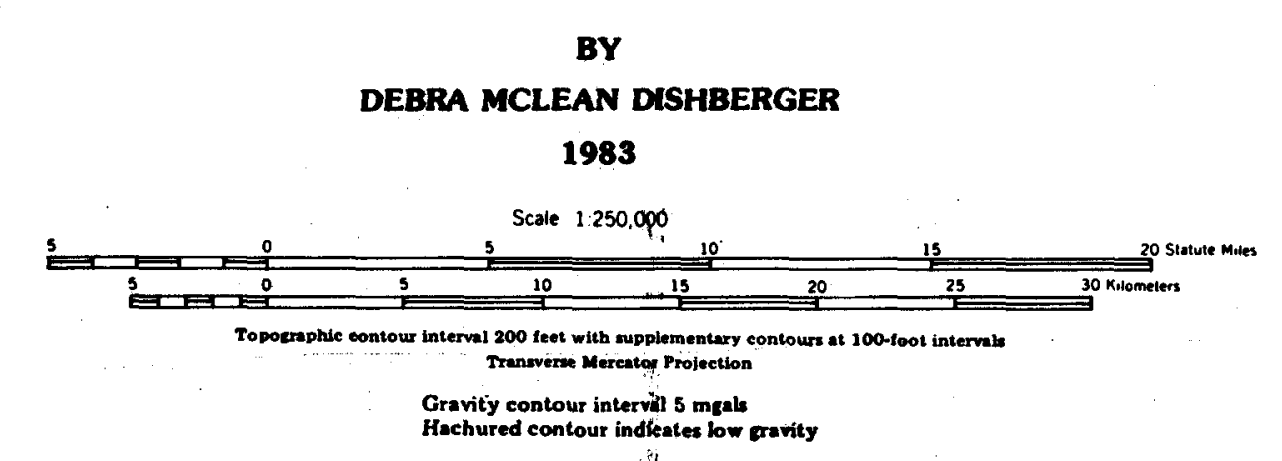




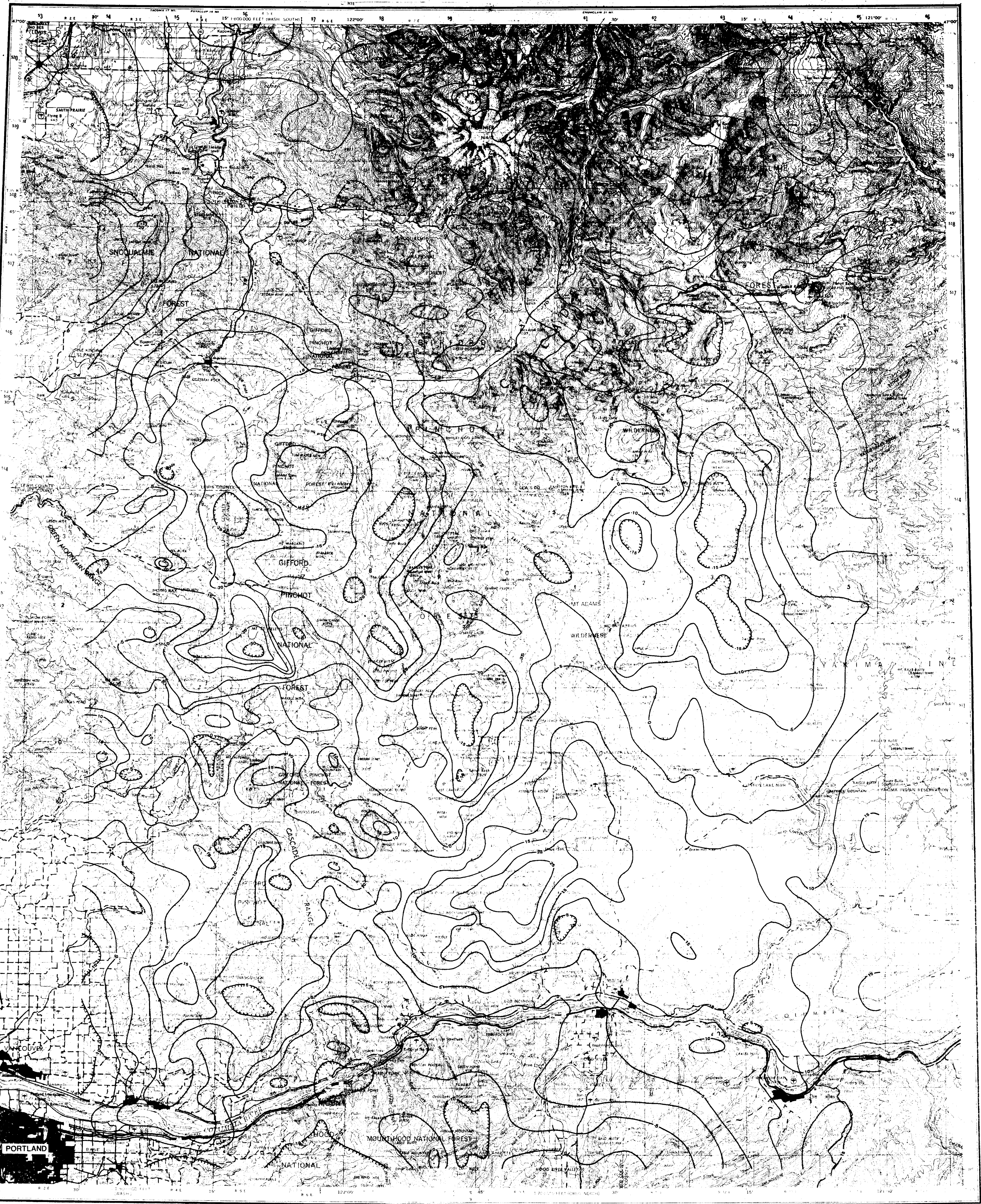

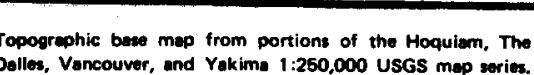

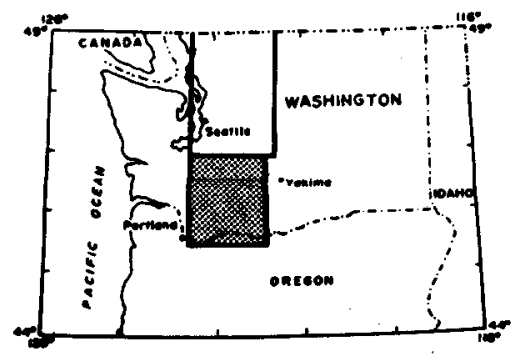

RESIDUAL GRAVITY MAP OF

THE SOUTHERN CASCADE MOUNTAINS, WASHINGTON

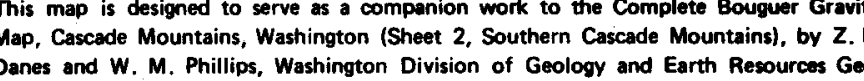

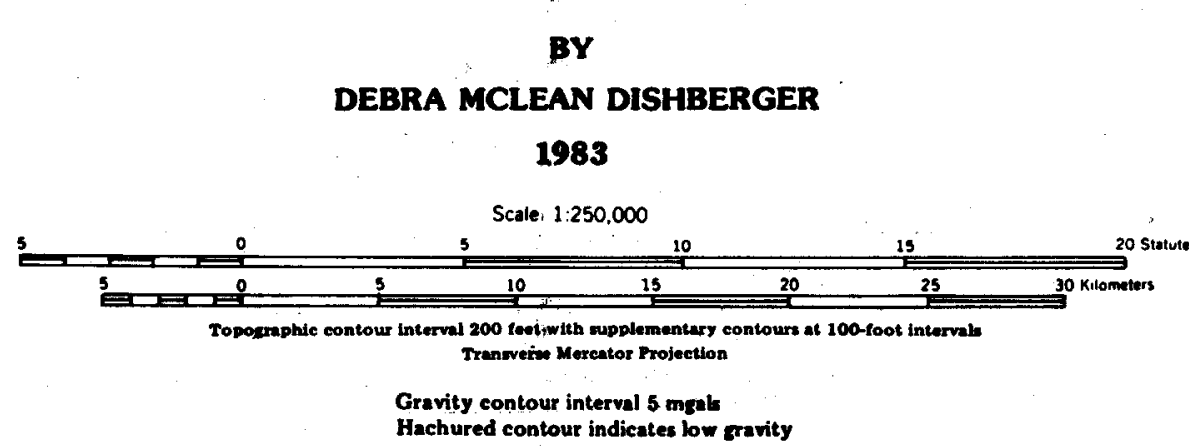




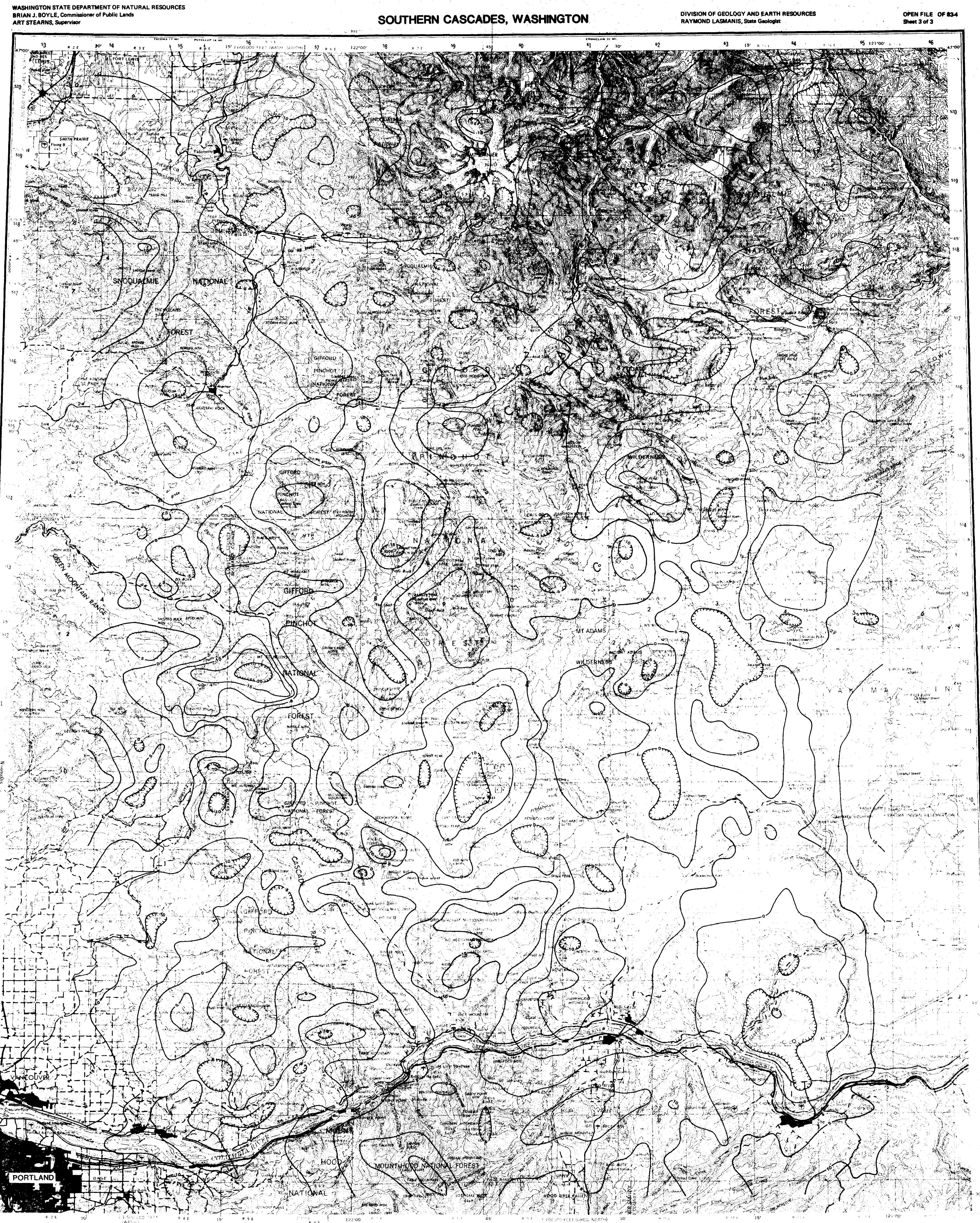

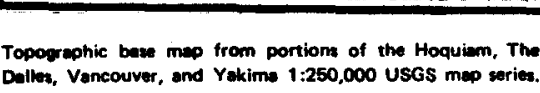

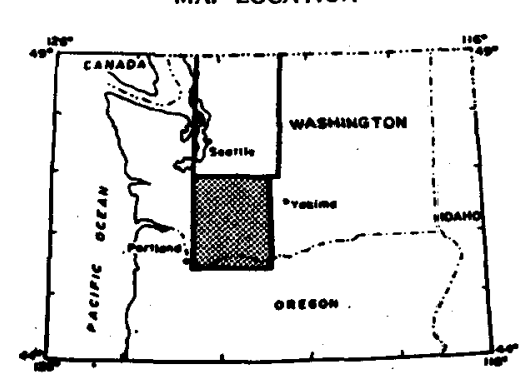

RESIDUAL GRAVITY MAP OF

THE SOUTHERN CASCADE MOUNTAINS, WASHINGTON

20 KILOMETER CUTOFF WAVELENGTH

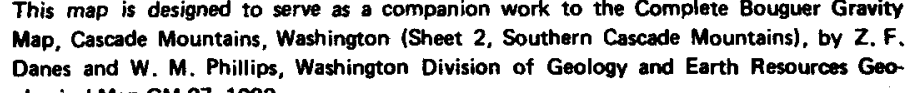

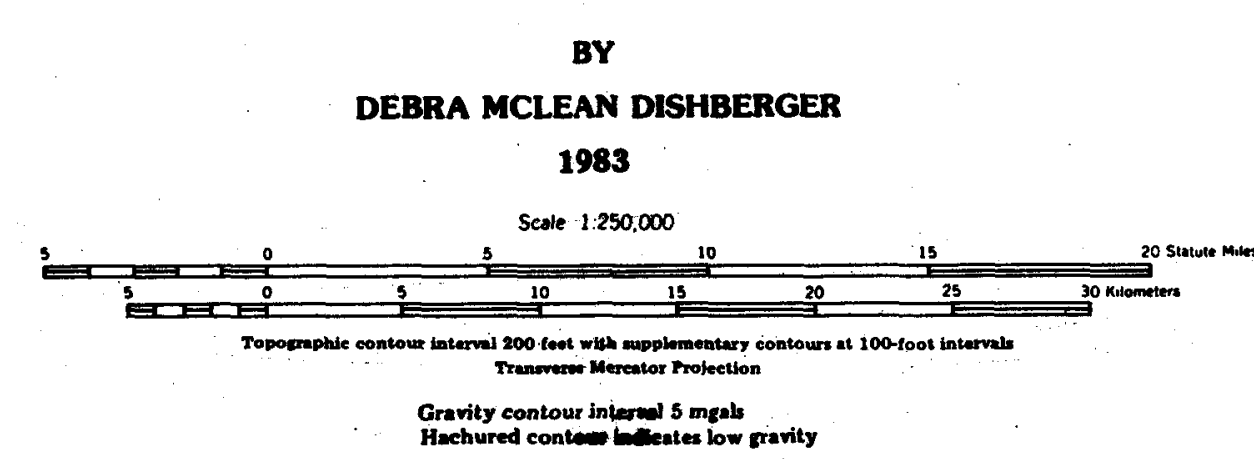

